\title{
Nanoparticles as a Tool for Broadening Antifungal Activities
}

\author{
Daniele Fernanda Renzi ${ }^{1}$, Laís de Almeida Campos ${ }^{1}$, Eduardo Hösel Miranda ${ }^{1}$, \\ Rubiana Mara Mainardes ${ }^{1}$, Wolf-Rainer Abraham ${ }^{2}$, Diana Fortkamp Grigoletto ${ }^{1}$ and \\ Najeh Maissar Khali1 ${ }^{1, *}$
}

${ }^{I}$ Pharmaceutical Nanotechnology Laboratory. Universidade Estadual do Centro-Oeste. Alameda Élio Antonio Dalla Vecchia, 838 - CEP 85040-167, Guarapuava-PR, Brasil; ${ }^{2}$ Helmholtz Center for Infection Research, Chemical Microbiology, Inhoffenstraße 7, 38124 Braunschweig, Germany

\begin{abstract}
Fungal infections are diseases that are considered neglected although their infection rates have increased worldwide in the last decades. Thus, since the antifungal arsenal is restricted and many strains have shown resistance, new therapeutic alternatives are necessary. Nanoparticles are considered important alternatives to promote drug delivery. In this sense, the objective of the present study was to evaluate the contributions of newly developed nanoparticles to the treatment of fungal infections. Studies have shown that nanoparticles generally improve the biopharmaceutical and pharmacokinetic characteristics of antifungals, which is reflected in a greater pharmacodynamic potential and lower toxicity, as well as the possibility of prolonged action. It also offers the proposition of new routes of administration. Nanotechnology is known to contribute to a new drug delivery system, not only for the control of 10.2174/0929867327666200330143338 infectious diseases but for various other diseases as well. In recent years, several studies have emphasized its application in infectious diseases, presenting better alternatives for the treatment of fungal infections.
\end{abstract}

Keywords: Azoles, echinocandins, fungal infection, nanotechnology, polyenes.

\section{INTRODUCTION}

Invasive fungal infections, although commonly regarded as neglected diseases, are among the leading causes of morbidity and mortality in hospitalized patients in recent decades, affecting approximately 1 billion people, with 11.5 million life-threatening infections and 1.5 million deaths per year $[1,2,3,4]$.

There are some risk factors associated with these infections, including immunocompromised patients undergoing invasive procedures [5], neonates [6], chemotherapy [7], burns [8], AIDS [9, 10], among others [11, 12]. In addition to these factors, socioeconomic conditions, geographical regions, and cultural habits are also important in the manifestation of these infections [13].

Fungal infections can develop as superficial, cutaneous, subcutaneous, and systemic mycoses, and indi-

\footnotetext{
*Address correspondence to this author at the Pharmaceutical Nanotechnology Laboratory. Universidade Estadual do Centro-Oeste. Alameda Élio Antonio Dalla Vecchia, 838 - CEP 85040-167, Guarapuava-PR, Brasil; E-mail: najehunicentro@hotmail.com
}

viduals living in endemic areas are more susceptible $[14,15]$. Endemic mycoses are caused by a group of fungi that share characteristics such as dimorphism and virulence factors that vary according to temperature and environment conditions. They are widespread opportunistic infections mainly in immunocompromised patients, being frequent in tropical and subtropical environments worldwide $[16,17,18]$.

Among opportunistic invasive infections, some fungal genera are considered more common, e.g. Candida sp., Cryptococcus sp. and Aspergillus sp., each with distinct pathophysiological and treatment characteristics $[19,20,12]$.

The demand for antifungals has increased in recent years, mainly due to the increase of immunocompromised patients with secondary diseases [11]. The availability of Class availability of these drugs is known to be restricted and studies have reported the presence of resistant strains [21, 22, 23]. In addition, there is a need for improvement in the pharmacokinetic 
characteristics of these drugs regarding their toxicity [24, 25].

Nanotechnology has been considered an important strategy to overcome biopharmaceutical, pharmacokinetic, and toxic problems of compounds with antifungal activity [26]. Furthermore, the development of antifungal encapsulation systems allows the controlled release of the drug and can protect the active principle of the gastrointestinal environment, allowing oral administration [27]. Nanoparticles have also shown a synergistic effect with antifungals $[28,29]$.

Although some studies report the role of nanoparticles in carrying antifungal drugs, they are still restricted. This review brings a broad discussion of the main nanostructured systems that transport compounds with antifungal activity, in order to collaborate in understanding of these systems and the advantages of their therapeutic application, as well as limitations.

\section{NANOPARTICLES AS DRUG CARRIERS}

Nanoencapsulation of drugs aims particles ranging in size from 1 to $1000 \mathrm{~nm}[30,31]$. The process of the development and the resulting structure of nanoparticles influences properties and characteristics related to drug release as well as pharmacokinetic and pharmacodynamic aspects can be dissolved. They drug of interest dissolved, adsorbed, or encapsulated in a matrix formed by polymers, proteins, or lipids [32, 33]. The nanoparticles are classified into nanocapsules, systems in which the drug is in a membrane-surrounded cavity, and nanospheres, in which the drug is dispersed in a matrix [34, 35]. In addition, nanoparticles are divided into classes according to their composition. There are ceramic [36], metallic [37], inorganic [38], carbonbased [39], polymeric [40], and lipid-based nanoparticles [41].

The main objective of nanostructured systems is the reduction of undesired effects caused by standard formulations, beyond which the physicochemical and biological properties of these systems enable their use as drug carriers [42, 43]. In the study of $\mathrm{Hu}$ et al. [44], bortezomib nanoparticles were less toxic to tissues than the free form of bortezomib. In addition, through suitable combinations, nanoparticles can be used with formulations that reduce toxicity, as in the study of Pereverzeva et al.[45], in which nanoformulations containing doxorubicin exhibited considerably reduced cardioand testicular toxicity, compared to a free drug. In oral formulations, nanoparticles protect the drug from degradation due to the acidic $\mathrm{pH}$ of the stomach [46].
Nanocarriers have been an important alternative in treating infections. Among the available models, lipid systems stand out for reducing both the pathogenicity of microorganisms and the toxicity in patients [47]. Moreover, it is important to emphasize that the evaluation of the best nanostructured system depends on the demands of each infection [48].

The use of nanoparticles in biomedical applications has shown important results because it allows improvement in the pharmacological aspects of the formulations and decrease in the toxic effects of the compounds, as well as an increase of the release time and stability, and opens the possibilities of various administration routes [49,50], as oral [51], intravenous [52], pulmonary [53], ocular [54], and topical $[55,56]$ (Fig. 1).

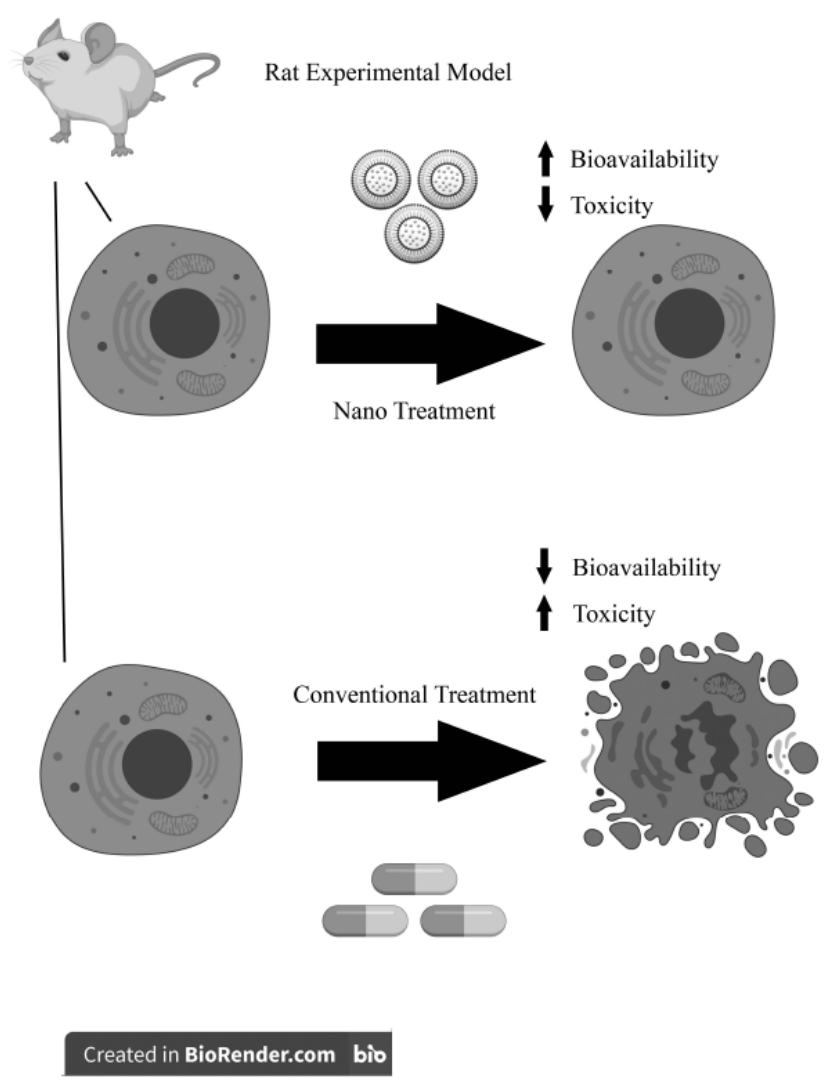

Fig. (1). Main advantages of using polymeric systems for antifungal administration in in vivo models. (A higher resolution / colour version of this figure is available in the electronic copy of the article).

In the last decades, several techniques have been developed to obtain nanoparticles for drug transport purposes [57]. For polymeric nanoparticles, the techniques, in general, can be divided into polymerization of monomers and dispersion of preformed polymers $[58,59]$. For the formation of nanoparticles from the polymerization of monomers, there is also the method 
of mini- [60], micro- [58], and macroemulsion [61] and interfacial polymerization [62].

For the formation of nanoparticles from polymer dispersion, one can use the techniques of solvent emulsification-evaporation [63, 64], nanoprecipitation [65], solvent homogenization diffusion [66], double emulsion and evaporation [67], double emulsion [68], salting-out [58], dialysis [69], spray drying [70], and supercritical fluid technology [71].

Techniques using preformed polymers are often prioritized for avoiding toxic waste compared to methods based on polymerization reactions [59]. In addition to these techniques, there are, for example, the flash nanoprecipitation method [72] and ionotropic gelation [73].

For the formation of lipid nanoparticles, the double emulsion method with solvent evaporation [67], solvent diffusion [74], high-pressure homogenization [75], among others, are available. Lipid nanoparticles are widely used in drug delivery systems due to their characteristics, such as lipids present in the formulations are similar to the body's natural lipids. In addition, they have controlled-release, higher bioavailability, lower dose, and higher tissue specificity [76].

In this context, nanoparticles have been developed to improve the characteristics of classical antifungals and molecules with inhibitory activity on the important fungi that cause invasive diseases [55].

\section{ANTIFUNGAL CLASSES}

The biggest obstacle in developing an effective antifungal is the similarity between the fungal cell and the animal (human) cell. Cholesterol is the main membrane sterol in human cells, while ergosterol is the main sterol in fungal cells, both are very similar [77]. Thus, antifungals aim at targets that differ between these two cell types. Cell wall components, fungal cell membrane, and RNA synthesis are common targets of some commercially available antifungals. Based on their mechanism of action, antifungals can be divided into polyenes, azoles, echinocandins, and those of intracellular action [78].

\subsection{Polyenes}

Polyenes are considered the oldest class of antifungals, and their main representatives are amphotericin B and nystatin. These antifungals are macrocyclic organic molecules that attach to the double layer of phospholipids in the fungal membrane and the complex formed leads to cell disruption $[79,80,81]$. However, other mechanisms of this class have also been investigated and described, mainly in relation to amphotericin B which seems to have its mechanism of action associated with the formation of reactive oxygen species (ROS), generally in resistance profile strains $[82,83]$.

Amphotericin B is the major representative of this class and was isolated around 1955 from a strain of Streptomyces nodosus [84]. This drug acts on most yeasts and filamentous fungi, such as Candida sp., Aspergillus sp., and Cryptococcus sp. Produced for intravenous administration, the main reported side effects of amphotericin B in patients are hepatotoxicity and nephrotoxicity $[85,86]$.

Due to its low solubility in water and in most organic solvents, amphotericin $\mathrm{B}$ is not well absorbed in the gastrointestinal tract $[87,88,89,90]$. Furthermore, this molecule possesses poor stability in gastric juice, which, despite being another disadvantage, is a relatively easily resolved compared to the low solubility [91]. These characteristics were tackled by studies that aim to increase solubility and decrease toxicity, for example through liposome formulations [92, 93, 94].

With respect to pharmacokinetics, about $95 \%$ of the amphotericin B is bound to proteins after administration. During the absorption process, higher concentrations of this drug may be found in organs such as the liver and spleen $[95,96]$. The elimination half-life of amphotericin B is considered to be slow, taking on average 15 days [97]. The use of the conventional amphotericin B formulation may cause some undesirable effects such as nausea, headache, and chills [98]. These symptoms may be caused by increased prostaglandin production, tumor necrosis factors, and interleukin-1 [99]. One of the benefits of lipid systems is the possible reduction of these mentioned symptoms $[100,101]$.

Nystatin is a polyene discovered in 1950 and isolated from the Gram-positive bacterium Streptomyces noursei. This drug has fungicidal and fungistatic activities and is widely used against infections caused by $C$. albicans [102]. Nystatin can be applied via topical creams as well as orally via oral suspensions and lozenges [103]. However, it has negligible absorption in the gastrointestinal tract, and high doses can cause nausea and vomiting [104]. Furthermore, nystatin is also able to induce secretion of interleukins and tumor necrosis factor-alpha by binding to Toll-like receptors present in immune cells, triggering a proinflammatory process [105].

Natamycin is a compound naturally produced by the bacterium Streptomyces natalenses, first isolated in 
1950 [106]. Due to its safety for humans, this drug is widely applied against yeasts and fungi [107]. It has in vitro activity against a variety of yeasts and filamentous fungi, such as Candida sp., Epidermophyton sp., Microsporum sp., and Trichophyton sp. This drug may also be used in the food industry as a preservative of dairy products [108]. Nevertheless, as previously reported for some antifungal agents, it has also low solubility in most solvents [109].

\subsection{Azoles}

Azoles are a class of synthetic antifungals that can be divided into imidazoles consisting of ketoconazole, miconazole, and clotrimazole and triazoles comprising itraconazole, fluconazole, voriconazole, and posaconazole. What differs between these two classes basically is the number of nitrogen atoms that form their aromatic rings (Fig. 2) [110].
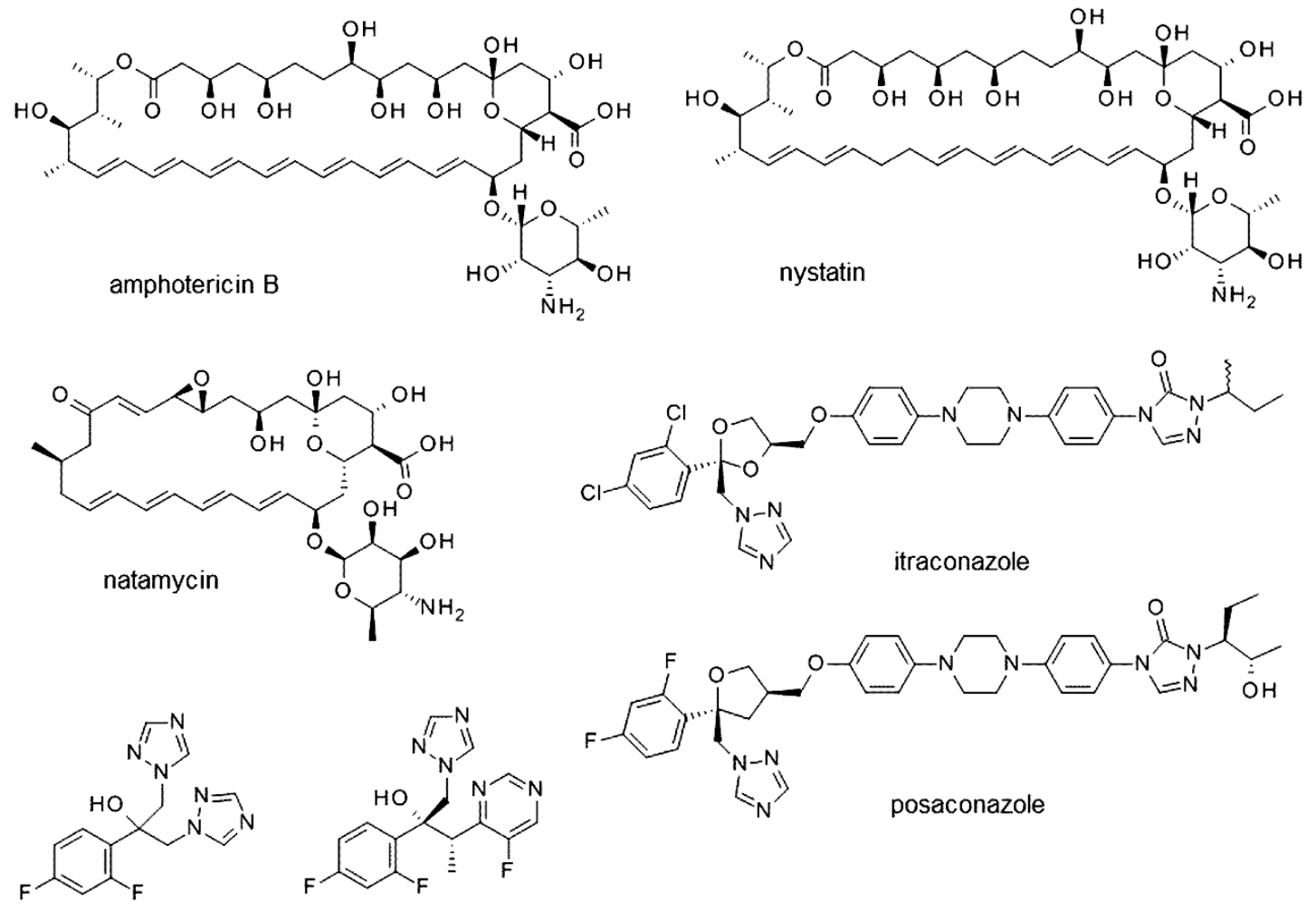

fluconazole

voriconazole

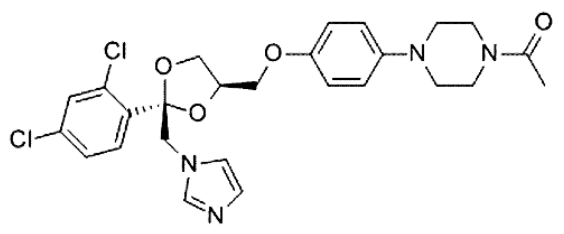

ketoconazole
The mechanism of action is related to the blockade of the $14 \alpha$-demethylase enzyme found in cytochrome P-450 in fungal cells, thus, there is no demethylation of the lanosterol precursor to yield ergosterol [111]. As a result, the amount of ergosterol is decreased, thereby altering the flowability of the cell membrane. In addition, azoles can also prevent the transformation of Candida sp. into hyphae, which is the pathogenic form of this fungus [112].

Fluconazole has a spectrum of action against Candida spp. such as $C$. albicans, $C$. tropicalis, $C$. glabrata, C. parapsilosis, and is effective in treating Cryptococcus neoformans, Histoplasma capsulatum, Coccidioides immitis, Blastomyces dermatitidis, Parracoccidioides brasiliensis, Sporothrix schenkii, Penicillium marneffei, among others [113, 114, 115]. It can be applied both in oral and parenteral administrations and is generally well absorbed by the gastrointestinal tract 
due to its hydrophilic properties. It has a low affinity for plasma proteins and is widely distributed throughout the body, including the central nervous system. Its bioavailability is considered excellent and its main side effect is hepatotoxicity $[116,117]$.

Itraconazole is used in oral and intravenous formulations [118] because it is a highly lipophilic drug [119], with low solubility and high permeability [120]. Following administration, the peak concentration is reached within 2 to 3 hours [121] and the half-life is approximately 24 hours [119]. Effective against strains of Candida sp. [122], Aspergillus sp. [119, 123], Zygomycetes, dimorphic fungi and causes of chromoblastomycosis, mycetoma, and phaeohyphomycosis [124], this drug has both fungicidal [125] and fungistatic activities [126]. In oral formulations, stomach $\mathrm{pH}$ may interfere with the absorption process, which occurs mainly in the proximal small intestine [127]. Itraconazole is a potent inhibitor of cytochrome P-450 and glycoprotein $\mathrm{P}$, making this process the likely mechanism of action in cases of drug interactions [128].

Voriconazole is a broad-spectrum triazole widely used against endemic fungi, for example, Candida spp. [129, 130], Aspergillus spp. [130], and Cryptococcus spp. [129]. This second-generation drug was derived from fluconazole, however, with a higher activity spectrum [131]. It has both fungicidal and fungistatic activities, according to the fungal species in question [132]. It can be found in formulations for oral [133] and intravenous administrations [134]. Voriconazole undergoes hepatic metabolism by P-450 family enzymes, mainly CYP2C19, CYP2C9, and CYP3A4. After this process, the produced inactive metabolites are mostly excreted via the urinary tract and a small percentage through the fecal pathway [135].

One of the latest antifungals introduced is posaconazole. This drug was developed from itraconazole and can be applied as an oral suspension. Posaconazole is effective against various strains, and its action occurs against Candida sp., Cryptococcus sp., Aspergillus sp., melanized, and dimorphic fungi [124, 130]. Its oral bioavailability also depends on stomach $\mathrm{pH}$, and absorption is higher in the presence of fatty foods [136]. Once absorbed, this drug undergoes phase I and II metabolism through the action of P-450 enzymes and the glucuronidation process [137]. Conditions such as diarrhea or concomitant use of some drug classes, such as subtype 2 histamine receptor antagonists [138], may interfere with posaconazole concentrations in blood. Elimination occurs mainly through the fecal pathway [139].
Ketoconazole was the first broad-spectrum antifungal developed against dermatophytes and yeasts [140]. In 1977, its introduction represented a major breakthrough in the class of antifungal drugs [141]. In 1980, it was the only oral antifungal agent to treat systemic infections. However, soon its adverse effects began to become apparent causing this drug to lose its application [131]. In Europe, this drug was withdrawn in 2013 from use due to side effects in patients, especially liver damage [142]. Its use has been indicated in these countries only in very serious cases of infections [141]. In addition, ketoconazole can inhibit several P-450 family enzymes causing an increase of sensitivity of the individual to other drugs [143]. These enzymes are directly related to the biotransformation process, and changes in its function or structure affect this process, harming the organism [144].

Clotrimazole is a synthetic compound widely used in vaginal and skin infections because it has good skin penetration and low systemic absorption [145]. Used to treat infections primarily caused by $C$. albicans, this drug also has activity against Gram-positive bacteria [146].

\subsection{Echinocandins}

Echinocandins are lipopeptides, more specifically semi-synthetic cyclic hexapeptides with $N$-modified acylated lipid side chains [147]. Although this class of antifungal acts on several classes of yeast in vitro, its action in vivo is considerable only for Candida sp. and Aspergillus sp. [148]. They represent the most recent class of antifungals compared to those previously presented. In the last decade, echinocandins have emerged as a first-line antifungal treatment to combat invasive candidiasis [147]. They target the enzyme $\beta-1,3$-glucan synthase responsible for the production of the $\beta-1,3-\mathrm{D}$ glucan present in the fungal cell wall. Inhibition of this enzyme affects membrane integrity and induces fungal cell disruption and subsequent death [149].

The class is represented by caspofungin, micafungin, and anidulafungin (Fig. 3) [148], which are administered only intravenously [150], not orally [147]. Caspofungin and micafungin are metabolized by the liver, while anidulafungin is broken down in the plasma when the macrocyclic ring opens [151].

The spectrum of applications includes the treatment of various diseases caused by Candida spp., such as esophageal candidiasis, candidemia, and invasive candidiasis, as well as invasive aspergillosis [149]. 


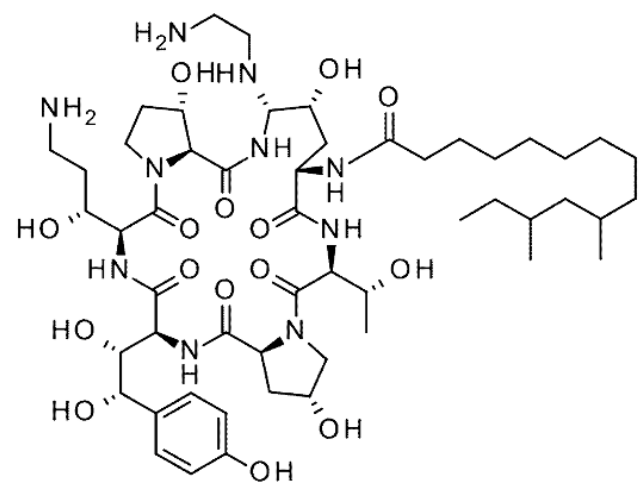

caspofungin

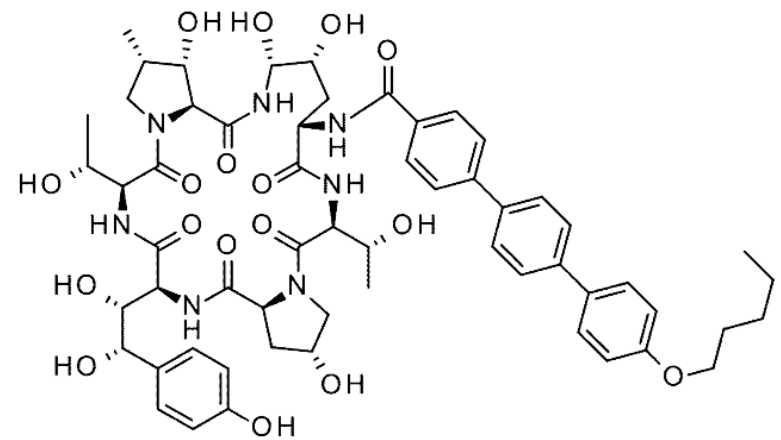

anidulafungin

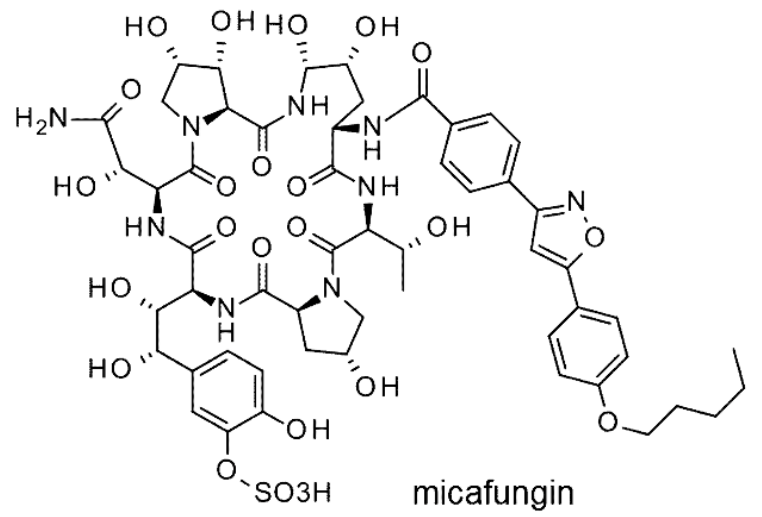

Fig. (3). Structures of echinocandins used as antifungals.

\subsection{Other Compounds}

There is also a class of antifungals that are able to act at the intracellular level, such as griseofulvin, a metabolite of Penicillium spp. [152] and flucytosine, a synthetic compound [153]. While griseofulvin acts by interfering with the fungal mitotic spindle and cytoplasmic microtubules [152], flucytosine inhibits the synthesis of nucleic acids and proteins of microorganisms, mainly Candida sp. [153].

Flucytosine is a prodrug that, when activated, is transported into cells by cytosine permease [154]. Its administration is by the oral route, where approximately $70 \%$ is absorbed, differing in relation to the other classes, by the low binding to plasma proteins and the high solubility in water $[155,156]$. In addition, this class of drugs is capable of penetrating to the cerebrospinal, peritoneal, and synovial fluid [155, 157]. The maximum concentration can be reached approximately 1 to 2 hours after administration. It is recommended to keep the plasma concentration between 40$80 \mu \mathrm{g} \mathrm{mL}{ }^{-1}$; elimination occurs mainly in the kidneys through glomerular filtration. Flucytosine therapies generally employ a second antifungal due to the development of fungal resistance [158].
Conventional drugs, despite their considerable efficacy, still offer less than optimal results due to the limitations present in some antifungal classes. Examples include low aqueous solubility and toxicity, which links the active principle to the establishment of new formulations $[159,160,161]$.

\section{ANTIFUNGAL DRUGS AND TOXICITY}

Antifungals can be grouped based on their mechanism of action in the fungal cell [162]. The major problems for the individual who needs this type of treatment are the side effects. Although the fungal cell exhibits some differences to the animal cell, such as the composition of its membrane and cell wall, the similarity between both is still large, which limits specific antifungal sites of action and increases the likelihood of toxicity $[163,78]$.

Currently available antifungals can be used to treat a range of infections in different parts of the body. During antifungal therapy, one of the main toxic effects reported is hepatotoxicity which may be related to factors including liver disease, physicochemical properties of the antifungal, disease severity, and drug interactions, more often observed for azole derivatives than for echinocandins $[164,165,166,167]$. These effects 
may be considered reversible after discontinuation of treatment and individualized therapy seems to overcome the problems related to toxicity in antifungal use [159].

Flucytosine may cause liver damage during treatment, but this condition may be reversed upon discontinuation of treatment. The exact mechanism is poorly known, but there is an association between dose and side effects, and dose reduction is indicated when necessary [168].

Griseofulvin is related to adverse effects, and animal studies demonstrated that it causes hepatocellular injury, cholestasis, and cirrhosis [169, 170, 171]. A case study of a young patient using griseofulvin and terbinafine reported the appearance of toxic epidermal necrolysis, but the condition could be reversed after discontinuation of treatment [172].

Fluconazole also shows hepatotoxicity, which may be asymptomatic in 5 to $10 \%$ of cases, and is dosedependent. The mechanism causing injuries is poorly understood, but fluconazole appears to involve different enzyme forms from other antifungals due to its low potency as a substrate for hepatic metabolism [164].

A study by Wang et al. [167] found that itraconazole provides a higher risk of developing liver damage than other antifungals. Despite elevated liver enzymes, in some cases, no interruption of treatment is required, but patients with some type of liver dysfunction should be monitored during therapy. In the same study, voriconazole showed similar results to itraconazole in relation to the damage caused [167]. At higher concentrations, the risk of liver damage increases and, in some cases, an increase in liver enzymes also occurs. A meta-analysis by Xing et al. [173] showed that voriconazole is associated with a higher risk of neurotoxicity, hepatotoxicity, and visual toxicity compared to other antifungals.

Enzymes can be slightly elevated during treatments with posaconazole but resolve after discontinuation of therapy, with fatalities due to liver failure only in a small number of patients with severe underlying diseases. However, common adverse effects include fever, headache, diarrhea, nausea, and vomiting. Severe conditions comprise pulmonary embolism, adrenal insufficiency, and allergic reactions [174].

The echinocandin class offers higher safety even when higher doses are required. There are rarely reports of cardiotoxicity associated with the way the drug was administered. The compounds caspofungin and micafungin are more likely to develop toxicity when compared to anidulafungin [151].

Nephrotoxicity may also occur due to renal vasoconstriction and subsequent reduction in blood flow caused by some antifungals $[175,176]$. Some side effects such as fever and chills, hypotension and hypertension, nausea, vomiting, hypoxia, and hypokalemia may be developed by patients [177]. These adverse effects are associated with proinflammatory cytokines and immunostimulation via Toll-like receptors present on the surface of immune cells [178].

Nephrotoxicity is a condition found in patients using amphotericin B with deoxycholate and is mainly associated with perfusion disorders and morbidity [179]. Hepatotoxicity, in deoxycholate and amphotericin B liposome formulations, is rarer and usually occurs after the administration of cumulative doses. The use of other drugs with hepatotoxic potential together with amphotericin B increases the chances of toxicity [164].

In studies with nystatin, a number of adverse effects have been reported by individuals who have used it. The reports usually mention vomiting, diarrhea, unpleasant taste, abdominal pain, headaches, and rash [180].

A study by França et al. [181] evaluated the toxicity of amphotericin B in VERO cell lines. VERO cell lines consist of a mixture of proximal and distal renal tubular cells. The results show that cytotoxicity depended on the time of drug exposure. At concentrations of 15 and $20 \mu \mathrm{g}$ per $\mathrm{ml}$, the cytotoxicity was higher after 18 hours of exposure. In addition, the possible mechanism of cytotoxic action of amphotericin B is related to damage to VERO cell lysosomes. The protective effect of nanoparticles containing amphotericin $B$ in VERO cell culture and erythrocytes are shown in Fig. (4).

Increased intracellular calcium is related to the toxicity of various pore-forming compounds in the cell, such as amphotericin B, causing cell lysis [151]. Amphotericin B in its standard formulation is highly toxic to VERO cell lines [182]. With the central objective of reducing antifungal-related toxicity, amphotericin $\mathrm{B}$, a standard drug used against various strains, was the first antifungal to be nano-encapsulated [183]. As concluded by Espuelas et al. [184] when studying amphotericin B toxicity in vivo, nanoparticles show lower toxicity due to a possible reduction in the accumulation of this drug in the kidneys and liver compared to standard 
amphotericin B; however, a higher dose is required to ensure the therapeutic effect.

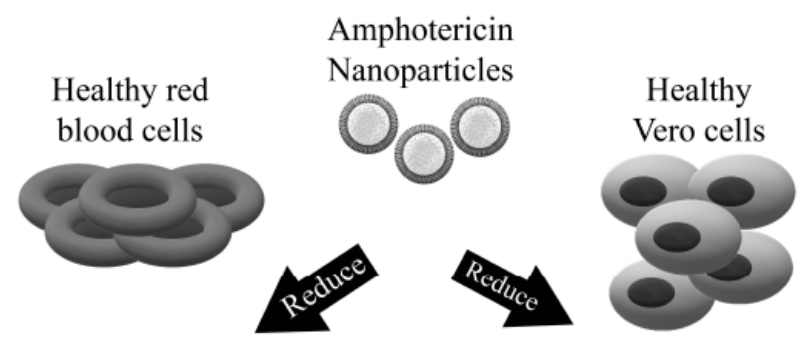

Cytotoxic effect

Cytotoxic effect
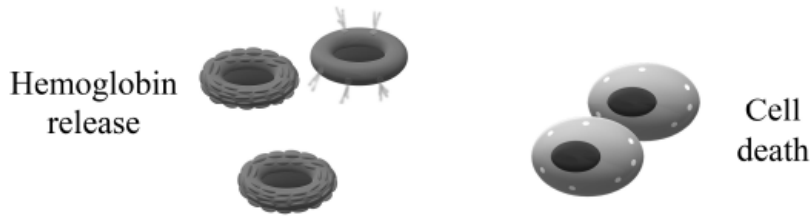

Cytotoxic effect

Cytotoxic effect

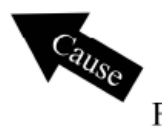

Free Form

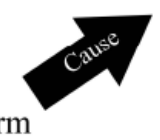

Amphotericin

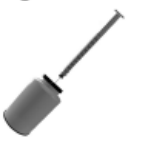

Fig. (4). Protective effect of a nanostructured model containing amphotericin $\mathrm{B}$ in VERO and red blood cell culture. ( $A$ higher resolution / colour version of this figure is available in the electronic copy of the article).

\section{MAIN NANOENCAPSULATED SYSTEMS CONTAINING ANTIFUNGALS}

\subsection{Amphotericin B}

Amphotericin B is considered as one of the main alternatives in the treatment of invasive infections. Commercial amphotericin B nanoforms are available, such as Fungizone sodium deoxycholate micelle and, more recently, lipid preparations such as Abelcet, Ambisome, and Amphocil/Amphotec, which have lower cytotoxicity than intravenous preparations, but still come with high costs and need therapeutic monitoring $[23,185,186]$.

In order to overcome limitations such as low water solubility and low absorption in the gastrointestinal tract, Gharib et al. [187] studied the development of nanospheres prepared by the spray-dried nanoprecipitation technique and obtained nanoparticles with higher efficacy and lower toxicity, in addition to the lower cost compared to other commercial nanosystems.
Oral delivery systems have been studied with the aim of reducing solubility problems, as well as providing comfort and decreased toxicity in patients [188]. Jain et al. [189] developed hybrid amphotericin B, lecithin, and gelatin nanoparticles by the desolvation method. These polymers are biocompatible, biodegradable, and inexpensive. Nanoformulation showed a sustained release profile and decreased hemolytic toxicity in relation to the free drug, but revealed gastrointestinal degradation, indicating the need for system coating. Jain et al. [190] characterized the use of bile saltstabilized chitosan nanoparticles for amphotericin B release. Nanoparticles were obtained by the ionic gelation method, with higher bioavailability, sustained release, increased gastrointestinal stability, and decreased hemolytic toxicity, characterizing a possible alternative for oral delivery of amphotericin B.

Although lipid carriers have increased oral bioavailability, the aggregation state of nanoparticles is still a limitation to some administration routes [89]. Jabri et al. [191] developed a hybrid gold and lecithin tragacanta gum nanoparticle system to increase the oral bioavailability of amphotericin B by the solvent diffusion method. The system presented encapsulation efficiency close to $78 \%$ and increased oral bioavailability in an animal model. The mucus helped to keep the drugs longer at the administration site, explaining the bioavailability. In addition, topical, nasal, and ocular release systems have also been developed with the same goal of reducing toxicity [192, 193, 194, 195].

Fu et al. [196] developed a lipid carrier for amphotericin $\mathrm{B}$ with the emulsion evaporation and lowtemperature solidification method for ocular administration and keratitis treatment. The system showed sustained in vitro release and better bioavailability, as well as the ability to successfully penetrate corneal tissue. Grisin et al. [197] developed chitosan and Pluronic chips for mucosal amphotericin B dispersion. The chips increased antifungal activity up to 4 times, possessed mucoadhesive capacity, and may be an alternative for use in hydrogels.

A pulmonary administration route studied by Shirkhani et al. [20] associated B-poly (methacrylic acid) (PMA) and anionic hydrogels for amphotericin B nebulization in a prophylactic manner. 99\% of Aspergillus sp. cells were killed and lung TNF- $\alpha$ was decreased by $90 \%$, which may qualify this hydrogel as an alternative route of administration for prophylactic exposures. In order to direct the tissue distribution of amphotericin B and to avoid toxic effects, Serrano et al. [198] developed nanoparticles of $N$-palmitoyl- $N$-monomethyl- $N$, 
$N$-dimethyl- $N, N$-trimethyl chitosan 6-O-glycol, and amphotericin B (GCPQ) with similar efficacy to the commercial form Ambisome (parenteral liposomal amphotericin B). GCPQ was able to act on specific organs such as lung, liver, and spleen, showing higher bioavailability and decreased renal exposure.

Despite its wide use in systemic infections, amphotericin B therapy is still restricted in some treatments such as fungal meningitis. Due to its pharmacokinetic characteristics, amphotericin B does not cross the blood-brain barrier [199]. Xu et al. [199] developed a nanoformulation that could circumvent this limitation in mice in a meningococcal meningitis model, in addition to reduced cytotoxicity in the liver, kidney, and blood. In the study by Ren et al. [52] using nanoprecipitation in poly (lactic acid)-b-poly (ethylene glycol) nanoparticles, it was observed that the concentration of the drug in the animals' brain increased, confirming that the formulation was able to cross the blood-brain barrier. In order to improve the distribution of amphotericin B in the central nervous system, Tang et al. [200] used a modified transferrin receptor antibody loaded with poly (lactic acid)/ poly (ethylene glycol) (PLA-PEG) to improve the passage of the antifungal through the blood-brain barrier.

Silver nanoparticles have been used in some systems as an alternative to antifungal activity, showing synergistic effects of amphotericin B and antifungal activity against some species of Candida sp., Aspergillus niger, and Fusarium culmorum [201, 202, 203]. Saldanha et al. [204] conducted a co-precipitation study with $\mathrm{Fe}_{3} \mathrm{O}_{4}$ and amphotericin $\mathrm{B}$ and tested it in an experimental model of paracoccidioidomycosis. They observed activity similar to free amphotericin, but with reduced adverse effects and number of applications.

In micelles developed by Diaz et al. [205], the nanoprecipitation system showed a reduction in red cell toxicity and greater antifungal activity in some Candida spp. compared to free amphotericin. The reduction in toxicity was accompanied by the slow release and low aggregation of the nanoparticle. The reduction of toxicity associated with low aggregation was also reported in the study by Chaudhari et al. [206].

The use of nanotechnology also favors the improvement of amphotericin B antifungal activity. Tang et al. [200] observed an increase of antifungal activity and survival rate of $95 \%$ in animals treated with amphotericin B nanoparticles with anti-Candida albicans antibody developed by the solvent evaporation emulsion technique.
Different polymers have been used to make amphotericin B polymeric nanoparticles. Among the polymers, poly lactic-co-glycolic acid (PLGA) [207], poly (lactic acid) (PLA) [208], polyethylene glycol (PEG), polycaprolactone (PCL) [209], and chitosan [141] are the most common, being developed by different techniques $[210,200]$. The main advantage of using these systems is their biocompatibility and biodegradability [211].

Despite the many efforts to overcome the limitations of administration and adverse effects of amphotericin $\mathrm{B}$, much remains to be understood regarding the distribution and interaction of these systems to ensure their use. However, undoubtedly, they are alternatives that bring improvements in patient therapy and facilitate treatment adherence.

\subsection{Voriconazole}

Nanostructured systems have shown important results mainly in reducing the undesirable effects of voriconazole administration. In addition to the possibility of sustained-release, which facilitates patient adherence to fungal infection treatments, one of the goals of using nanotechnology is also related to improving the solubility of voriconazole in aqueous media, or allowing new routes of administration [212, 213]. In order to provide new routes of administration for voriconazole besides the oral one, nanotechnology has been explored for ocular $[54,214,215,216]$, pulmonary [53, 217, $218,219]$, and nail [220] distribution routes.

Due to the low water solubility of voriconazole, Füredi et al. [216] developed lipid-based nanoparticles by high-pressure homogenization for parenteral administration. The nanoparticles obtained had a size of $81.2 \mathrm{~nm}$ and encapsulation efficiency close to $70 \%$, allowing doubling of the solubility of voriconazole.

Polymers are an important alternative for the development of nanoparticles with pharmacological interest, mainly for their biodegradable and biocompatible characteristics. Sinha et al. [53] encapsulated voriconazole in porous and nonporous PLGA nanoparticles for pulmonary administration. PLGA was also an alternative in the studies by Das et al. [218] and Paul et al. [219] in nanoparticles for pulmonary release. This alternative is interesting because it allowed prolonged release and better bioavailability, as well as deposition in the lung tissue.

Ocular administration has been stimulated as another route for voriconazole medication, especially in cases of fungal keratitis [215]. Kumar and Sinha [54] 
observed sustained release of voriconazole into ocular tissue by the use of solid lipid nanoparticles, offering an alternative for the treatment of fungal keratitis due to good corneal permeation. A thermogel was developed by Cuming et al. [215] for ocular release by subconjunctival injection, allowing the reduction of the effects of ocular keratitis in animal models.

Aiming to improve the treatment of ocular keratitis, Huang et al. [221] developed hybrid contact lenses based on quaternized chitosan, silver, and graphene oxide through electrostatic interactions. The lens enabled sustained release of voriconazole into corneal tissue and increased antifungal efficacy in an in vitro model. Pawar et al. [222] developed an ophthalmic gel based on Pluronic F-127 or the combination of Pluronic F-68 and sodium alginate by in situ gelation. In addition to the sustained release of voriconazole, decreased toxicity was observed, which may increase patient compliance.

There are still some limitations regarding the treatment of fungal infections with voriconazole. In addition to side effects, variability in pharmacokinetic behavior remains an important limitation to be overcome, which requires pharmacokinetic studies of nanotechnology models.

\subsection{Fluconazole}

It is one of the most widely used azole antifungals in skin infections and systemic infections, especially in a hospital setting. However, one of the most recent limitations on fluconazole use is the emergence of resistant strains [223, 224, 225]. Among the main administration routes developed for fluconazole delivery, the topical route is used the most [226, 227], however, still existing is the ocular route [228].

In the study by Kelidare et al. [229], a lipid carrier system was developed using the ultrasound technique. This carrier was evaluated for activity against Candida sp. strains, and a reduction in the MICs of susceptible strains and strains previously resistant to fluconazole was achieved. This demonstrates the potential of studies involving nanotechnology and microorganisms.

\subsection{Ketoconazole}

To solve absorption-related problems, Modi et al. [230] developed chitosan-based mucoadhesive ketoconazole nanoparticles with an average size of $382 \mathrm{~nm}$ and approximately $69 \%$ mucin binding. The nanoparticles showed prolonged release of the drug even after gastric emptying, proving the success of the study.
Winnicka et al. [231] constructed a Bronopol and Carbopol 980-based hydrogel with ketoconazole dendrimers for topical administration, which improved the solubility and in vitro release of ketoconazole and increased up to 16-fold the antifungal activity of prepared hydrogels. Martin et al. [232] performed a study of gelled castor oil-based organogels using ketoconazole as a model for lipophilic drugs. In the study, encapsulation efficiency was approximately $98 \%$ with stability greater than 3 months and particle sizes between 250 and $300 \mathrm{~nm}$. The in vitro release profile showed immediate release of the drug due to its rapid diffusion.

Kumar et al. [233] evaluated ketoconazole nanoparticles of chitosan and gellan gum for topical administration and observed higher antifungal activity than the free drug in Aspergillus niger. The system had an average size of $155 \mathrm{~nm}$ and a zeta potential of 32.1 $\mathrm{mV}$. Another alternative for topical administration was developed by Mahtab et al. [234] for the nail treatment of onychomycosis, with an average size of $77 \mathrm{~nm}$. In this study, antifungal activity superior to ketoconazole solution was achieved, in addition to increased permeation and safe topical use. In addition to being used in the treatment of onychomycosis and cutaneous mycoses, ketoconazole is also an alternative in the treatment of keratitis. Ahmed and Aljaeid [235] developed a gel with PLGA by in vitro gelation and obtained a higher antifungal activity than the free drug.

\subsection{Nystatin}

Efforts to improve the absorption and permeability characteristics of nystatin have been undertaken [236]. For this, nystatin nanoparticles were developed by Mohammadi et al. [237] for the purpose of systemic administration and increased uptake of the drug by microbial cells. The results showed that nystatin and PLA + glucosamide nanoparticles demonstrated appropriate antifungal activity and physicochemical characteristics.

Fernández-Campos et al. [238] developed a nanoemulsion for nystatin release in the treatment of oral candidiasis and observed increased antifungal effects. The same group developed a nanoemulsion for topical administration of nystatin and obtained higher absorption than the pharmaceutical form [290]. Another topical release system has been studied by Khalil et al. [239], where the objective was to prepare nanoparticles for topical application. Prolonged-release and better efficacy could be obtained in their study.

\subsection{Flucytosine}

Nanostructured systems have been used to increase flucytosine permeability in different tissues. Salem et 
al. [217] incorporated flucytosine into gold nanoparticles to increase intraocular penetration and to evaluate the therapeutic efficacy of this topically applied formulation. In addition to intraocular permeation, Salem et al. [240] used glutathione to increase flucytosine permeation through the blood-brain barrier, achieving a system with an average size of $100 \mathrm{~nm}$ and $70 \%$ drug release. Both efforts are promising alternatives for flucytosine release in different tissues. A relationship to some of the nanostructured systems developed in recent years with flucytosine and the main antifungal drugs can be seen in Table $\mathbf{1}$.

\section{CO-ENCAPSULATION OF ANTI-FUNGAL}

In addition to conventional nanostructured systems, the use of co-encapsulated compounds appears to be a promising alternative as it allows placing two antifungals into one formulation, reducing the dose of each drug used. This concept has been partially put into practice using amphotericin B, rapamycin and 5fluorocytosine in a nanostructured system. It was observed that the drugs were able to act moderately synergistically against $C$. albicans strains [273].

Some nanomaterials can be used as antifungals as well, e.g. silver nanoparticles are naturally effective against microorganisms [274] and chitosan, which can interact with the fungal cell wall and interfere with growth [275]. In the study by Longue et al. [224], the combination of fluconazole with silver nanoparticles reduced MIC 16- to 64-fold in C. albicans cells. Sun et al. [276] observed the synergistic effect of silver nanoparticles combined with antifungals, demonstrating moderate inhibitory action on resistant strains. Silver nanoparticles adhered to the fungal cell membrane, inhibited budding, and promoted the loss of membrane integrity.

Costa et al. [277] developed a mucoadhesive system of polymeric nanoparticles for the treatment of vulvovaginal candidiasis with miconazole, farnesol, and chitosan. The system was effective in inhibiting antifungal proliferation and decreasing pathogenicity. Kalita et al. [278] co-encapsulated chloramphenicol with lemongrass essential oil in PCL-Pluronic nanocapsules and obtained a significant reduction in cytotoxicity with increased in vitro antimicrobial activity against 22 microbial pathogens, including three Candida spp. Still in the line of natural products, Svetlichny et al. [279] developed solid lipid nanoparticles containing copaiba oil with and without allantoin to evaluate their antifungal activity. They concluded that nanoencapsulation improved the antifungal activity of copaiba oil, which was enhanced by the presence of allantoin. MICs obtained against $C$. krusei, C. parapsilosis, Trichophyton rubrum, and Microsporum canis were comparable to those of commercial products, offering promising therapies for skin infections.

There are also studies on the formation of micelles containing an antifungal and a compound that adds beneficial properties to the antifungal, as shown in the study of Diezi and Kwon [280]. Here, amphotericin B was co-encapsulated with cholesterol in PEGphospholipid micelles, meeting the safety and solubility requirements for amphotericin $\mathrm{B}$, causing low in vitro hemolysis and reduced toxicity, as well as efficacy against $C$. albicans.

In addition to micelles, there are bifunctional viscous nanovesicles, which range from 130 to $190 \mathrm{~nm}$. Vitonyte et al. [281] studied resveratrol and gallic acid co-charged nanovesicles to protect the skin against oxidative damage and microorganisms, including Candida sp. The authors concluded that if phenols were dispersed in a water/glycerol mixture, the inhibitory effect against Candida sp. (in the planktonic state) could be increased.

This demonstrates the potential combining more than one drug in the same nanostructured system. Ideally, studies in this line should be intensified so that new data could be made available, enriching the knowledge about co-encapsulated antifungals.

\section{GREEN SYNTHESIS OF NANOPARTICLES}

The green synthesis of nanoparticles has gained importance due to the ecological aspect $[282,283]$, which reduces the use of toxic chemicals, in addition to being, often, a simple and inexpensive process [284]. For this, components from microbial cells $[282,285]$ and plants [286] can be used, which are sources of potential reducing agents [287]. As an example of green synthesis, we can mention the study by Jogaiah et al. [282], who used the extract of the basidiomycete Ganoderma applanatum for the synthesis of silver nanoparticles. Nandini et al. [285] used the membrane lipids of Trichoderma spp. along with Tween 80 for the composition of a nanoemulsion by the ultrasonic emulsification method, and Nayak et al. [286] used the extract of the medicinal plant Dillenia indica. Sarkar et al. [283] used extracts from the plant Adiantum lunulatum for the synthesis of copper oxide nanoparticles. Thakur et al. [284] synthesized titanium dioxide nanoparticles using the extract of the leaves of the Azadirachta indica plant. The use of plant extracts and microorganisms gives nanoparticles several biological activities, 
Table 1. Nanostructured systems developed with major antifungals in the last 9 years.

\begin{tabular}{|c|c|c|c|c|c|c|}
\hline $\begin{array}{l}\text { Antifungal } \\
\text { Drug }\end{array}$ & Composition & Method & $\begin{array}{l}\text { Route of Ad- } \\
\text { ministration }\end{array}$ & Efficiency & Toxicity & Refs. \\
\hline Voriconazole & $\begin{array}{l}\text { Lipids (Stearic acid, } \\
\text { Witepsol, Compritol) }\end{array}$ & $\begin{array}{l}\text { High-pressure ho- } \\
\text { mogenization }\end{array}$ & Ocular & $\begin{array}{l}\text { Voriconazole ef- } \\
\text { fective against } \\
\text { strains of C. albi- } \\
\text { cans and A.flavus }\end{array}$ & - & [216] \\
\hline Voriconazole & Poly-lactide-co-glycolide & $\begin{array}{l}\text { Multiple emulsifica- } \\
\text { tion }\end{array}$ & Pulmonary & $\begin{array}{l}\text { Better lung depo- } \\
\text { sition }\end{array}$ & - & {$[53]$} \\
\hline Voriconazole & $\begin{array}{l}\text { Lipids (Compritol, } \\
\text { Miglyol, gelucire) }\end{array}$ & $\begin{array}{l}\text { Hot and high pres- } \\
\text { sure homogeniza- } \\
\text { tion }\end{array}$ & Oral & $\begin{array}{c}\text { Voriconazole } \\
\text { nanoparticles have } \\
\text { higher efficiency } \\
\text { against } C \text {. albi- } \\
\text { cans }\end{array}$ & - & [241] \\
\hline Voriconazole & Precitol, Labrafil & $\begin{array}{l}\text { High pressure ho- } \\
\text { mogenization }\end{array}$ & Topical & $\begin{array}{l}\text { Increased skin } \\
\text { retention and per- } \\
\text { meation of vori- } \\
\text { conazole }\end{array}$ & - & [212] \\
\hline Voriconazole & $\begin{array}{l}\text { Oleic acid, sodium deoxy- } \\
\text { cholate, polyoxyethylene }\end{array}$ & - & Topical & $\begin{array}{l}\text { Microemulsions } \\
\text { containing vori- } \\
\text { conazole for topi- } \\
\text { cal administration }\end{array}$ & - & [213] \\
\hline Voriconazole & $\begin{array}{c}\text { Carbopol 934, stearic acid, } \\
\text { Tween } 80\end{array}$ & Ultrasonication & Ocular & $\begin{array}{l}\text { Improved tech- } \\
\text { nique used for } \\
\text { nanoparticle } \\
\text { preparation }\end{array}$ & - & [214] \\
\hline Voriconazole & $\begin{array}{l}\text { Soy phosphatidylcholine, } \\
\text { 1,2-dioleoyl-3- } \\
\text { trimethylammonium pro- } \\
\text { pane, cholesterol }\end{array}$ & Thin-film hydration & Ocular & $\begin{array}{l}\text { Liposomes with } \\
\text { promising topical } \\
\text { antifungal action }\end{array}$ & - & [242] \\
\hline Voriconazole & $\begin{array}{l}\text { Chitosan, silver and gra- } \\
\text { phene oxide }\end{array}$ & $\begin{array}{l}\text { Electrostatic inter- } \\
\text { action }\end{array}$ & Ocular & $\begin{array}{l}\text { Hydrogel contact } \\
\text { lenses with anti- } \\
\text { fungal activity }\end{array}$ & $\begin{array}{l}\text { Mild cationic } \\
\text { toxicity in } \\
\text { HTCC groups }\end{array}$ & [221] \\
\hline Voriconazole & $\begin{array}{l}\text { Pluronic F-127, sodium } \\
\text { alginate }\end{array}$ & Gelation in situ & Ocular & $\begin{array}{l}\text { Stability and pro- } \\
\text { longed effect } \\
\text { against strains of } \\
\text { C. albicans and } A \text {. } \\
\quad \text { fumigatus }\end{array}$ & - & {$[222]$} \\
\hline Voriconazole & PLGA, chitosan & $\begin{array}{l}\text { Emulsion solvent } \\
\text { evaporation }\end{array}$ & Pulmonary & $\begin{array}{c}\text { Better delivery } \\
\text { and bioavailability } \\
\text { of coated formula- } \\
\text { tions }\end{array}$ & - & [219] \\
\hline Voriconazole & $\begin{array}{l}\text { Carbopol, methylcellulose, } \\
\text { lecithin, and cholesterol }\end{array}$ & Film hydration & Ocular & $\begin{array}{l}\text { Prolonged drug } \\
\text { release }\end{array}$ & - & [243] \\
\hline
\end{tabular}

(Table 1) contd.... 


\begin{tabular}{|c|c|c|c|c|c|c|}
\hline $\begin{array}{l}\text { Antifungal } \\
\text { Drug }\end{array}$ & Composition & Method & $\begin{array}{l}\text { Route of Ad- } \\
\text { ministration }\end{array}$ & Efficiency & Toxicity & Refs. \\
\hline Voriconazole & $\begin{array}{l}\text { Stearic acid, sodium de- } \\
\text { oxycholate }\end{array}$ & Emulsification & Pulmonary & $\begin{array}{l}\text { Increased deposi- } \\
\text { tion and dissolu- } \\
\text { tion in the lung }\end{array}$ & - & [217] \\
\hline Voriconazole & PLGA & $\begin{array}{l}\text { Multiple emulsion } \\
\text { by solvent evapora- } \\
\text { tion }\end{array}$ & Pulmonary & $\begin{array}{c}\text { Improved delivery } \\
\text { and longer excre- } \\
\text { tion time of } \\
\text { nanoparticle for- } \\
\text { mulation }\end{array}$ & - & [218] \\
\hline Voriconazole & $\begin{array}{l}\text { Compritol, palmitic acid, } \\
\text { Poloxamer and soy leci- } \\
\text { thin, sodium taurocholate }\end{array}$ & $\begin{array}{l}\text { Emulsification/ } \\
\text { evaporation }\end{array}$ & Ocular & $\begin{array}{l}\text { Development, } \\
\text { characterization, } \\
\text { and delivery }\end{array}$ & - & [244] \\
\hline Fluconazole & $\begin{array}{l}\text { Carbopol, precirol, oleic } \\
\text { acid, Kolliphor }\end{array}$ & $\begin{array}{l}\text { Lipid suspension by } \\
\text { inversion tempera- } \\
\text { ture }\end{array}$ & Topical & $\begin{array}{l}\text { Gel with stable, } \\
\text { long-acting and } \\
\text { located action }\end{array}$ & - & [245] \\
\hline Fluconazole & PLGA & $\begin{array}{l}\text { Double emulsion } \\
\text { solvent diffusion }\end{array}$ & Oral & $\begin{array}{c}\text { Improvement in } \\
\text { antifungal activity } \\
\text { against } C \text {. albi- } \\
\text { cans }\end{array}$ & $\begin{array}{c}\text { Moderate toxic- } \\
\text { ity against } \\
\text { VERO cell lines }\end{array}$ & [246] \\
\hline Fluconazole & Span $80 / 60$, Tween 80 & Ultrasonication & Oral & $\begin{array}{c}\text { Solid lipid } \\
\text { nanoparticles as a } \\
\text { delivery alterna- } \\
\text { tive }\end{array}$ & - & [225] \\
\hline Fluconazole & $\begin{array}{l}\text { Compritol } 888 \text { ATO, oleic } \\
\text { acid, phosphatidylcholine, } \\
\text { and Pluronic F-68 }\end{array}$ & Solvent diffusion & Topical & $\begin{array}{c}\text { Carrier, pro- } \\
\text { longed-release and } \\
\text { localized effect }\end{array}$ & - & [223] \\
\hline Fluconazole & Oleic acid & Film hydration & Topical & $\begin{array}{l}\text { Sustained release } \\
\text { and retention of } \\
\text { the drug in the } \\
\text { deepest part of the } \\
\text { skin }\end{array}$ & - & [227] \\
\hline Fluconazole & $\begin{array}{c}\text { Span 40, Span } 60 \text { and Brij } \\
72\end{array}$ & Film hydration & Topical & $\begin{array}{l}\text { Localized effect, } \\
\text { sustained release } \\
\text { of drug }\end{array}$ & - & [247] \\
\hline Fluconazole & $\begin{array}{c}\text { Hyaluronic acid and cho- } \\
\text { lesterol / Tween } 80 \text { / } \\
\text { Transcutol HP / Maisine } \\
\text { 35-1 / Caproyl } 90\end{array}$ & $\begin{array}{l}\text { Hydration of lipid } \\
\text { film }\end{array}$ & Ocular & $\begin{array}{l}\text { Increased corneal } \\
\text { permeability }\end{array}$ & $\begin{array}{l}\text { No inflamma- } \\
\text { tory response or } \\
\text { signs of eye } \\
\text { toxicity }\end{array}$ & [228] \\
\hline Fluconazole & PCL & $\begin{array}{l}\text { Interfacial deposi- } \\
\text { tion and high pres- } \\
\text { sure homogeniza- } \\
\text { tion }\end{array}$ & Oral & $\begin{array}{c}\text { Effective dose } \\
\text { reduction of flu- } \\
\text { conazole and re- } \\
\text { sistance reversal in } \\
\text { Candida } \text { sp. tested }\end{array}$ & - & [248] \\
\hline
\end{tabular}




\begin{tabular}{|c|c|c|c|c|c|c|}
\hline $\begin{array}{l}\text { Antifungal } \\
\text { Drug }\end{array}$ & Composition & Method & $\begin{array}{l}\text { Route of Ad- } \\
\text { ministration }\end{array}$ & Efficiency & Toxicity & Refs. \\
\hline Fluconazole & $\begin{array}{c}\text { Compritol } 888 \text { ATO, } \\
\text { phosphatidylcholine and } \\
\text { Pluronic F-68 }\end{array}$ & Solvent diffusion & Topical & $\begin{array}{l}\text { Improvement in } \\
\text { dermal localiza- } \\
\text { tion }\end{array}$ & - & [249] \\
\hline Fluconazole & PVA & Electrospinning & Topical & $\begin{array}{c}\text { Sustained 6-hour } \\
\text { drug release and } \\
\text { superior activity } \\
\text { against } C \text {. albi- } \\
\text { cans }\end{array}$ & $\begin{array}{l}\text { Through local } \\
\text { application, } \\
\text { reduction of } \\
\text { systemic toxicity }\end{array}$ & {$[250]$} \\
\hline Fluconazole & $\begin{array}{c}\text { Stearic acid/ Compritol } \\
\text { 1,888 ATO, oleic acid and } \\
\text { Span } 80\end{array}$ & Probe ultrasound & - & $\begin{array}{c}\text { Effectiveness } \\
\text { against Candida } \\
\text { sp. with different } \\
\text { susceptibilities to } \\
\text { conventional flu- } \\
\text { conazole formula- } \\
\text { tions }\end{array}$ & - & [229] \\
\hline Ketoconazole & $\begin{array}{l}\text { Carbopol 980, propylene } \\
\text { glycol, Tween } 80 \text {, bro- } \\
\text { nopol, PAMAM-NH2 and } \\
\text { PAMAM-OH dendrimers } \\
\text { generation } 2 \text { and genera- } \\
\text { tion } 3\end{array}$ & - & Topical & $\begin{array}{l}\text { PAMAM-NH2 } \\
\text { dendrimers in- } \\
\text { creased the anti- } \\
\text { fungal activity of } \\
\text { ketoconazole } \\
\text { against strains of } \\
\text { Candida }\end{array}$ & - & [231] \\
\hline Ketoconazole & Castor oil, HSA, PVA & Hot emulsification & Topical & $\begin{array}{l}\text { Better bioavail- } \\
\text { ability }\end{array}$ & - & [232] \\
\hline Ketoconazole & - & Ball milling & Oral & $\begin{array}{c}\text { Increased effi- } \\
\text { ciency against } \\
\text { yeast and biofilms } \\
\text { of Candida } \mathrm{sp} .\end{array}$ & - & {$[188]$} \\
\hline Ketoconazole & $\begin{array}{l}\text { PLGA, alginate, and chito- } \\
\text { san }\end{array}$ & $\begin{array}{l}\text { Freezing by solvent } \\
\text { exchange in vitro }\end{array}$ & Ocular & $\begin{array}{c}\text { Good transcorneal } \\
\text { permeation and } \\
\text { antifungal activity }\end{array}$ & - & {$[235]$} \\
\hline Ketoconazole & $\begin{array}{l}\text { Carbopol Ultrez 21, thio- } \\
\text { glycolic acid }\end{array}$ & $\begin{array}{l}\text { Aqueous titration } \\
\text { followed by high } \\
\text { pressure homogeni- } \\
\text { zation }\end{array}$ & Nail/ Topical & $\begin{array}{l}\text { Antifungal effect } \\
\text { on Trichophyton } \\
\text { rubrum and Can- } \\
\text { dida albicans }\end{array}$ & $\begin{array}{c}\text { Skin irritation } \\
\text { and histopathol- } \\
\text { ogy studies in rat } \\
\text { skin showed safe } \\
\text { topical use }\end{array}$ & [234] \\
\hline Ketoconazole & Chitosan, gellan gum & $\begin{array}{l}\text { Electrostatic com- } \\
\text { plexation }\end{array}$ & Oral & $\begin{array}{c}\text { Significantly } \\
\text { higher antifungal } \\
\text { activity against } \\
\text { Aspergillus niger }\end{array}$ & - & [233] \\
\hline Nystatin & $\begin{array}{c}\text { Emulgade, glycerol } \\
\text { monostearate and salty oil }\end{array}$ & $\begin{array}{l}\text { High-pressure ho- } \\
\text { mogenization }\end{array}$ & Oral & - & - & [251] \\
\hline
\end{tabular}

(Table 1) contd.... 


\begin{tabular}{|c|c|c|c|c|c|c|}
\hline $\begin{array}{c}\text { Antifungal } \\
\text { Drug }\end{array}$ & Composition & Method & $\begin{array}{l}\text { Route of Ad- } \\
\text { ministration }\end{array}$ & Efficiency & Toxicity & Refs \\
\hline Nystatin & $\begin{array}{l}\text { Alginate, chitosan, Polox- } \\
\text { amer } 407\end{array}$ & $\begin{array}{l}\text { Emulsification / } \\
\text { internal gelation }\end{array}$ & Topical & $\begin{array}{l}\text { Antifungal effect } \\
\text { against Candida } \\
\text { albicans }\end{array}$ & $\begin{array}{c}\text { Antifungal effect } \\
\text { without toxic } \\
\text { systemic absorp- } \\
\text { tion }\end{array}$ & {$[252]$} \\
\hline Nystatin & Alginate, chitosan & $\begin{array}{l}\text { Emulsification/ } \\
\text { internal gelation }\end{array}$ & Topical & $\begin{array}{l}\text { Antifungal effect } \\
\text { against Candida } \\
\text { albicans }\end{array}$ & $\begin{array}{c}\text { No tissue dam- } \\
\text { age and no pres- } \\
\text { ence in the } \\
\text { bloodstream }\end{array}$ & {$[253]$} \\
\hline Nystatin & $\begin{array}{l}\text { Sodium alginate, chitosan } \\
\text { stearate }\end{array}$ & $\begin{array}{l}\text { Ionotropic com- } \\
\text { plexation }\end{array}$ & Oral & $\begin{array}{l}\text { More localized } \\
\text { distribution rela- } \\
\text { tive to Leishma- } \\
\text { nia-infected or- } \\
\text { gans (spleen and } \\
\text { liver) }\end{array}$ & $\begin{array}{c}\text { Less toxic for- } \\
\text { mulation in vitro } \\
\text { and in vivo com- } \\
\text { pared to simple } \\
\text { amphotericin B }\end{array}$ & {$[254]$} \\
\hline Amphotericin B & Ethylene glycol, PEG & $\begin{array}{l}\text { Electrostatic and } \\
\text { hydrophobic inter- } \\
\text { actions }\end{array}$ & Oral & $\begin{array}{c}\text { Higher antifungal } \\
\text { potential }\end{array}$ & $\begin{array}{c}\text { Decreased neph- } \\
\text { rotoxicity and } \\
\text { hemolysis }\end{array}$ & {$[255]$} \\
\hline Amphotericin B & PLGA, PLGA-PEG & $\begin{array}{l}\text { Emulsification sol- } \\
\text { vent evaporation }\end{array}$ & Oral & $\begin{array}{c}\text { Antifungal activity } \\
2 \mathrm{x} \text { and } 10 \mathrm{x} \text { higher } \\
\text { in PLGA-PEG and } \\
\text { PLGA nanoparti- } \\
\text { cles than free am- } \\
\text { photericin B on } C \text {. } \\
\text { albicans, being a } \\
\text { potential nanocar- } \\
\text { rier }\end{array}$ & $\begin{array}{c}\text { Decrease in } \\
\text { hemolysis toxic- } \\
\text { ity to } 2 \text { and } 5 \% \\
\text { compared to free } \\
\text { amphotericin B }\end{array}$ & {$[207]$} \\
\hline Amphotericin B & PLGA & Nanoprecipitation & Oral & $\begin{array}{l}\text { Minimum inhibi- } \\
\text { tory concentration } \\
\text { lower than free } \\
\text { amphotericin B }\end{array}$ & $\begin{array}{l}\text { Activity on red } \\
\text { cells } 9.5 \mathrm{x} \text { less } \\
\text { toxic compared } \\
\text { to free ampho- } \\
\text { tericin B }\end{array}$ & {$[187]$} \\
\hline Amphotericin B & $\begin{array}{c}\text { Polybutylcyanoacrylate, } \\
\text { Polysorbate } 80 \text {, acetic acid, } \\
\text { Dextran T-70 }\end{array}$ & $\begin{array}{l}\text { Spontaneous ani- } \\
\text { onic polymerization }\end{array}$ & Oral & $\begin{array}{l}\text { Ability to cross } \\
\text { the blood-brain } \\
\text { barrier. } \\
\text { Detection of minor } \\
\text { fungal colonies in } \\
\text { nanoparticle } \\
\text { treated groups in } \\
\text { relation to ampho- } \\
\text { tericin B deoxy- } \\
\text { cholate and am- } \\
\text { photericin B } \\
\text { liposome }\end{array}$ & $\begin{array}{c}\text { Increased animal } \\
\text { survival after } 7 \\
\text { days of treat- } \\
\text { ment. Reduction } \\
\text { of toxicity in } \\
\text { liver, kidney, } \\
\text { and blood. }\end{array}$ & {$[199]$} \\
\hline Amphotericin B & Chitosan, lecithin & Ionic gelation & Ocular & $\begin{array}{l}\text { approximately } 2 \mathrm{x} \\
\text { higher bioavail- } \\
\text { ability, longer } \\
\text { residence time in } \\
\text { tissue. Antifungal }\end{array}$ & - & {$[256]$} \\
\hline
\end{tabular}




\begin{tabular}{|c|c|c|c|c|c|c|}
\hline $\begin{array}{l}\text { Antifungal } \\
\text { Drug }\end{array}$ & Composition & Method & $\begin{array}{l}\text { Route of Ad- } \\
\text { ministration }\end{array}$ & Efficiency & Toxicity & Refs. \\
\hline & & & & $\begin{array}{l}\text { activity lower than } \\
\text { the commercial } \\
\text { formulation, } \\
\text { which may be } \\
\text { associated with a } \\
\text { prolonged-release } \\
\text { time of the } \\
\text { nanoparticle }\end{array}$ & & \\
\hline Amphotericin B & TPGS, PLGA & Nanoprecipitation & Oral & $\begin{array}{c}\text { Encapsulation } \\
\text { efficiency of } 85 \% \text {. } \\
\text { Nanoparticles } \\
\text { showed increased } \\
\text { bioavailability and } \\
\text { lower minimum } \\
\text { inhibitory concen- } \\
\text { tration compared } \\
\text { to free ampho- } \\
\text { tericin on } C \text {. albi- } \\
\text { cans }\end{array}$ & $\begin{array}{l}\text { Reduction of red } \\
\text { cell toxicity in } \\
\text { relation to free } \\
\text { amphotericin B }\end{array}$ & [257] \\
\hline Amphotericin B & PLGA & Nanoprecipitation & Oral & $\begin{array}{l}\text { Higher efficacy } \\
\text { compared to } \\
\text { commercial for- } \\
\text { mulations of Am- } \\
\text { bisome or } \\
\text { Fungizone that are } \\
\text { administered par- } \\
\text { enterally. }\end{array}$ & - & [210] \\
\hline Amphotericin B & PLGA-TPG & $\begin{array}{l}\text { Double modified } \\
\text { emulsion }\end{array}$ & Oral & $\begin{array}{c}\text { Increased } \\
\text { bioavailability and } \\
\text { survival of ani- } \\
\text { mals. In addition, } \\
\text { higher antifungal } \\
\text { activity in kidney, } \\
\text { liver, lung, and } \\
\text { spleen compared } \\
\text { to amphotericin B }\end{array}$ & 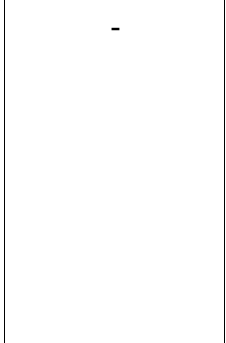 & [200] \\
\hline Amphotericin B & MPEG, PCL & Solvent diffusion & Topical & $\begin{array}{c}\text { The system } \\
\text { showed improved } \\
\text { solubility and } \\
\text { efficacy on } C \text {. } \\
\text { albicans biofilm. }\end{array}$ & $\begin{array}{l}\text { Decreased oral } \\
\text { epithelial cell } \\
\text { toxicity and } \\
\text { increased cell } \\
\text { viability in vivo }\end{array}$ & [258] \\
\hline Amphotericin B & $\begin{array}{l}\text { Campmul PG8, Labrasol } \\
\text { and polyethylene glycol }\end{array}$ & $\begin{array}{l}\text { Spontaneous titra- } \\
\text { tion }\end{array}$ & Topical & $\begin{array}{c}\text { Antifungal effect } \\
\text { against } C \text {. albi- } \\
\text { cans and Aspergil- } \\
\text { lus niger }\end{array}$ & - & [259] \\
\hline Amphotericin B & PLGA, chitosan & $\begin{array}{l}\text { Emulsification sol- } \\
\text { vent evaporation }\end{array}$ & Oral & $\begin{array}{l}\text { Increased release } \\
\text { time and ampho- } \\
\text { tericin B-like anti- } \\
\text { fungal activity }\end{array}$ & $\begin{array}{c}\text { Reduction of } \\
\text { hemolysis com- } \\
\text { pared to }\end{array}$ & [192] \\
\hline
\end{tabular}

(Table 1) contd.... 


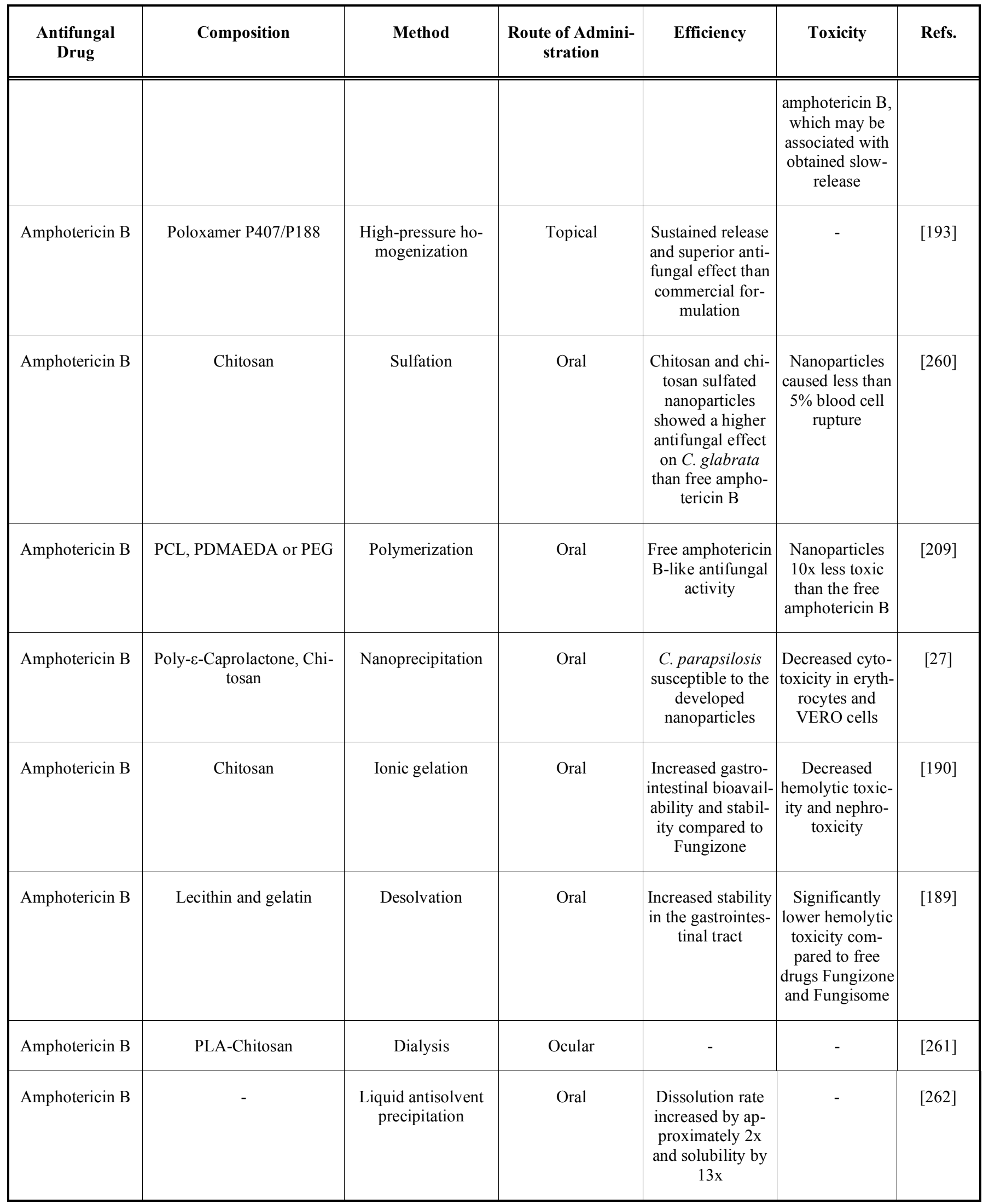




\begin{tabular}{|c|c|c|c|c|c|c|}
\hline $\begin{array}{l}\text { Antifungal } \\
\text { Drug }\end{array}$ & Composition & Method & $\begin{array}{l}\text { Route of Ad- } \\
\text { ministration }\end{array}$ & Efficiency & Toxicity & Refs. \\
\hline Amphotericin B & $\mathrm{Fe}_{3} \mathrm{O}_{4}$ & Ultrasonication & Intravenous & $\begin{array}{l}\text { May strengthen } \\
\text { brain targeting }\end{array}$ & $\begin{array}{l}\text { Reduction of } \\
\text { drug toxicity } \\
\text { when injected } \\
\text { with magnetic } \\
\text { field effect }\end{array}$ & [263] \\
\hline Amphotericin B & Chitosan and porphyran & Complexation & Oral & $\begin{array}{l}\text { Higher in vitro } \\
\text { and in vivo anti- } \\
\text { fungal activity } \\
\text { compared to } \\
\text { commercial for- } \\
\text { mulation }\end{array}$ & $\begin{array}{l}\text { Hemolytic toxic- } \\
\text { ity suggesting } \\
\text { safety in the } \\
\text { prepared } \\
\text { formulation }\end{array}$ & [264] \\
\hline Amphotericin B & $\begin{array}{l}\text { Isoprene- } \beta \text {-ethylene } \\
\text { polyoxide }\end{array}$ & Solvent evaporation & Oral & $\begin{array}{c}\text { The nanostructure } \\
\text { was able to encap- } \\
\text { sulate lipophilic } \\
\text { drugs }\end{array}$ & - & [265] \\
\hline Amphotericin B & Silver & - & Oral & $\begin{array}{c}\text { Antifungal activity } \\
\text { on C. albicans and } \\
\text { C. tropicalis }\end{array}$ & $\begin{array}{l}\text { Possible reduc- } \\
\text { tion of drug- } \\
\text { related toxicity }\end{array}$ & [201] \\
\hline Amphotericin B & $\mathrm{Fe}_{3} \mathrm{O}_{4}$ & Coprecipitation & Nasal & $\begin{array}{l}\text { Important antifun- } \\
\text { gal activity and } \\
\text { reduced number of } \\
\text { applications }\end{array}$ & $\begin{array}{l}\text { No clinical, bio- } \\
\text { chemical, geno- } \\
\text { toxic and histo- } \\
\text { pathological } \\
\text { changes were } \\
\text { observed }\end{array}$ & [204] \\
\hline Amphotericin B & PDMAEMA-B-PCL & Nanoprecipitation & Oral & $\begin{array}{c}\text { Antifungal activity } \\
\text { against } C \text {. albi- } \\
\text { cans, } C \text {. krusei } \\
\text { and } C \text {. glabrata }\end{array}$ & $\begin{array}{c}\text { Toxicity reduc- } \\
\text { tion }\end{array}$ & [205] \\
\hline Amphotericin B & CGPLAP, Miglyol 812 & $\begin{array}{l}\text { Nanoprecipitation } \\
\text { with spontaneous } \\
\text { emulsification }\end{array}$ & Oral & $\begin{array}{l}21-47 \% \text { encapsu- } \\
\text { lation efficiency }\end{array}$ & - & [266] \\
\hline Amphotericin B & PLGA & Double emulsion & Oral & $\begin{array}{l}\text { CFU reduction; } \\
\text { effective against } \\
\text { biofilm }\end{array}$ & $\begin{array}{l}\text { Toxicity reduc- } \\
\text { tion }\end{array}$ & [267] \\
\hline Amphotericin B & Caprylate / Caprate & $\begin{array}{l}\text { High pressure } \\
\text { homogenization }\end{array}$ & Oral & $\begin{array}{l}\text { Optimized car- } \\
\text { riage vehicle }\end{array}$ & - & [101] \\
\hline Amphotericin B & $\begin{array}{l}\text { Carboxymethyl Car- } \\
\text { rageenan, Gelatin A }\end{array}$ & Desolvation & Oral & - & $\begin{array}{c}\text { No hemolytic } \\
\text { disorder detected }\end{array}$ & [268] \\
\hline Amphotericin B & $\begin{array}{l}\text { Lecithin, sodium cholate } \\
\text { and oleic acid }\end{array}$ & Solvent diffusion & Oral & - & - & [269] \\
\hline
\end{tabular}

(Table 1) contd.... 


\begin{tabular}{|c|c|c|c|c|c|c|}
\hline $\begin{array}{l}\text { Antifungal } \\
\text { Drug }\end{array}$ & Composition & Method & $\begin{array}{l}\text { Route of Ad- } \\
\text { ministration }\end{array}$ & Efficiency & Toxicity & Refs. \\
\hline Amphotericin B & Gelatines A and B (GNPs) & Desolvation & Oral & $\begin{array}{c}\text { Low cost and safe } \\
\text { delivery }\end{array}$ & $\begin{array}{l}\text { No increased } \\
\text { hematological } \\
\text { toxicity and } \\
\text { nephrotoxicity }\end{array}$ & [270] \\
\hline Amphotericin B & $\begin{array}{l}\text { Compritol } 888 \text { ATO, Pre- } \\
\text { cirol ATO 5, Pluronic-F68 }\end{array}$ & Solvent diffusion & Topical & $\begin{array}{l}\text { Increased permea- } \\
\text { tion and antifungal } \\
\text { activity against } \\
\text { Trichophyton } \\
\text { rubrum }\end{array}$ & $\begin{array}{l}\text { Less skin irrita- } \\
\text { bility }\end{array}$ & [195] \\
\hline Amphotericin B & PLGA, PLH, PEG & $\begin{array}{c}\text { Emulsion solvent } \\
\text { evaporation }\end{array}$ & Pulmonary & $\begin{array}{c}\text { Improved } \\
\text { bioavailability and } \\
\text { antifungal activity }\end{array}$ & $\begin{array}{l}\text { Toxicity reduc- } \\
\text { tion }\end{array}$ & [200] \\
\hline Amphotericin B & PLA-PEG, Tween 80 & Nanoprecipitation & Intravenous & $\begin{array}{l}\text { Increased mouse } \\
\text { brain drug concen- } \\
\text { tration and thera- } \\
\text { peutic efficacy }\end{array}$ & $\begin{array}{l}\text { Liver, kidney } \\
\text { and blood toxic- } \\
\text { ity reduction }\end{array}$ & {$[52]$} \\
\hline Amphotericin B & PLA-PEG & $\begin{array}{l}\text { Emulsion solvent } \\
\text { evaporation }\end{array}$ & Oral & $\begin{array}{l}\text { Controlled release } \\
\text { system and stabil- } \\
\text { ity }\end{array}$ & - & [208] \\
\hline Amphotericin B & PLGA & Nanoprecipitation & Oral & $\begin{array}{l}\text { Increased efficacy } \\
\text { in vivo against } A . \\
\text { fumigatus }\end{array}$ & $\begin{array}{l}\text { Toxicity reduc- } \\
\text { tion }\end{array}$ & [271] \\
\hline Amphotericin B & Stearic acid, PVA 9000 & Coacervation & Oral & $\begin{array}{l}\text { Increased antifun- } \\
\text { gal activity }\end{array}$ & - & {$[272]$} \\
\hline
\end{tabular}

which shows an advantage in the agricultural and medical-pharmacological areas [288, 289].

\section{TOXICITY OF THE NANOPARTICLES}

The nanoparticles have been produced with the objective of increasing the beneficial properties of the encapsulated drug and reducing its toxic and unwanted effects, releasing the drug gradually and, consequently, improving its pharmacokinetics aspects [42, 43]. However, due to their high surface-to-volume ratio, the surface of nanomaterials is very reactive. When nanoparticles are absorbed and exposed to biological fluids, the components of these fluids, such as proteins and biomolecules, tend to associate with the surface of the nanoparticles, causing an interaction at the cellular and molecular levels [291]. Depending on the size, the nanoparticles are absorbed by different organs and tissues. There are also reports of nanoparticles that pass through the blood-brain barrier [291] and cause brain toxicity [293]. In the study by Sohaebuddin et al. [294], it was found that the composition and size of nanomaterials determine cell responses, as well as the type of target cell. However, despite this and many other studies in the area, reports on cell toxicity are still inconsistent [294].

\section{CONCLUSION}

The main limitations of antifungals currently available in the market, besides the emergence of resistant strains, are related to the adverse effects caused by them and the available administration routes, which often make patient compliance difficult. Nevertheless, the solubility and degradation characteristics on the gastrointestinal system need to be improved for more efficient oral administration.

In this sense, nanotechnology has been used as a valuable tool for the development of several antifungal release systems, as reported throughout this review. And many of them yielded interesting results regarding 
in vitro studies, such as prolonged release, decreased adverse effects, and increased antifungal activity. However, a fact that hinders their therapeutic applications. Although there are reports on the possible toxicity of nanoparticles due to their nanometric size, the advantages of these nanostructured systems are more significant.

Among the commercially available antifungals, amphotericin $\mathrm{B}$, has the best application results in the form of nanoparticles. Nevertheless, therapeutic monitoring of mainly hepatic and renal cytotoxicity is still extremely important, especially in immunocompromised patients.

The co-encapsulation of antifungals system seems to be a strategy of great relevance for patients, due to reduction of the side effects due to the high doses of conventional antifungals.

It is noticeable an urgency of new antifungals. Also, the improvement of the available arsenal is a great strategy to overcome the side and toxic effects, as well as, to secure the efficacy against more resistant strains. Nanostructured systems open a new avenue for antifungal therapeutic.

\section{CONSENT FOR PUBLICATION}

Not applicable.

\section{FUNDING}

This study was financed in part by the Coordenação de Aperfeiçoamento de Pessoal de Nível Superior Brasil (CAPES) - Finance Code 001 and National Council for Scientific and Technological Development $(\mathrm{CNPq} /$ Brazil), with scholarship granted to D.F.Grigoletto (159815/ 2018-5).

\section{CONFLICT OF INTEREST}

The authors declare no conflict of interest, financial or otherwise.

\section{ACKNOWLEDGEMENTS}

The authors thank Universidade Estadual do CentroOeste (UNICENTRO), National Council for Scientific and Technological Development (CNPq) and Coordenação de Aperfeiçoamento de Pessoal de Nível Superior (CAPES).

\section{REFERENCES}

[1] Cole, D.C.; Govender, N.P.; Chakrabarti, A.; Sacarlal, J.; Denning, D.W. Improvement of fungal disease identification and management: combined health systems and public health approaches. Lancet Infect. Dis., 2017, 17(12), e412e419.

http://dx.doi.org/10.1016/S1473-3099(17)30308-0 PMID: 28774694

[2] Suleyman, G.; Alangaden, G.J. Nosocomial fungal infections: epidemiology, infection control, and prevention. Infect. Dis. Clin. North Am., 2016, 30(4), 1023-1052.

http://dx.doi.org/10.1016/j.idc.2016.07.008 PMID: 27816138

[3] Tudela, J.L.R.; Denning, D.W. Recovery from serious fungal infections should be realisable for everyone. Lancet Infect. Dis., 2017, 17(11), 1111-1113. http://dx.doi.org/10.1016/S1473-3099(17)30319-5 PMID: 28774695

[4] Kidd, S.E.; Chen, S.C.; Meyer, W.; Halliday, C.L. A new age in molecular diagnostics for invasive fungal disease: are we ready? Front. Microbiol., 2020, 10, 2903. http://dx.doi.org/10.3389/fmicb.2019.02903 PMID 31993022

[5] Omrani, A.S.; Almaghrabi, R.S. Complications of hematopoietic stem transplantation: Fungal infections. Hematol. Oncol. Stem Cell Ther., 2017, 10(4), 239-244. http://dx.doi.org/10.1016/j.hemonc.2017.05.013 PMID: 28636889

[6] Calley, J.L.; Warris, A. Recognition and diagnosis of invasive fungal infections in neonates. J. Infect., 2017, 74(Suppl. 1), S108-S113.

http://dx.doi.org/10.1016/S0163-4453(17)30200-1 PMID: 28646949

[7] Mousset, S.; Buchheidt, D.; Heinz, W.; Ruhnke, M.; Cornely, O.A.; Egerer, G.; Krüger, W.; Link, H.; Neumann, S.; Ostermann, H.; Panse, J.; Penack, O.; Rieger, C.; Schmidt-Hieber, M.; Silling, G.; Südhoff, T.; Ullmann, A.J.; Wolf, H-H.; Maschmeyer, G.; Böhme, A. Treatment of invasive fungal infections in cancer patients-updated recommendations of the Infectious Diseases Working Party (AGIHO) of the German Society of Hematology and Oncology (DGHO). Ann. Hematol., 2014, 93(1), 13-32. http://dx.doi.org/10.1007/s00277-013-1867-1 PMID: 24026426

[8] Renau, A.I.; García-Vidal, C.; Salavert, M. Enfermedades invasivas por hongos levaduriformes en pacientes quemados graves. Rev. Iberoam. Micol., 2016, 33(3), 160-169. http://dx.doi.org/10.1016/j.riam.2016.02.002 PMID: 27395025

[9] Limper, A.H.; Adenis, A.; Le, T.; Harrison, T.S. Fungal infections in HIV/AIDS. Lancet Infect. Dis., 2017, 17(11), e334-e343.

http://dx.doi.org/10.1016/S1473-3099(17)30303-1 PMID: 28774701

[10] Rodríguez-Cerdeira, C.; Arenas, R.; Moreno-Coutiño, G.; Vásquez, E.; Fernández, R.; Chang, P. Micosis sistémicas em pacientes con vírus de la immunodeficiencia humana/sida. Actas Dermosifiliogr., 2014, 105, 5-17. http://dx.doi.org/10.1016/j.ad.2012.06.017 PMID: 23107866

[11] Richardson, M.; Lass-Flörl, C. Changing epidemiology of systemic fungal infections. Clin. Microbiol. Infect., 2008, 14(Suppl. 4), 5-24.

http://dx.doi.org/10.1111/j.1469-0691.2008.01978.x PMID: 18430126

[12] Schmiedez, Y.; Zimmerli, S. Common invasive fungal disease: an overview of invasive candidiasis, aspergillosis, cryptococcosis, and pneumocystis pneumonia. Swiss Med. Wkly., 2016, 146

http://dx.doi.org/10.4414/smw.2016.14281 
[13] Dong, D.; Li, Z.; Zhang, L.; Jiang, C.; Mao, E.; Wang, X.; Peng, Y. Clinical and microbiological investigation of fungemia from four hospitals in China. Mycopathologia, 2015, 179(5-6), 407-414.

http://dx.doi.org/10.1007/s11046-014-9855-0 PMID: 25720562

[14] Ghosh, A.; Magar, D.G.; Thapa, S.; Nayak, N.; Talwar, O.P. Histopathology of important fungal infections-A summary. J. Pathol. Nepal, 2019, 9, 1490-1496. http://dx.doi.org/10.3126/jpn.v9i1.23377

[15] Salzer, H.J.F.; Burchard, G.; Cornely, O.A.; Lange, C.; Rolling, T.; Schmiedel, S.; Libman, M.; Capone, D.; Le, T.; Dalcolmo, M.P.; Heyckendorf, J. Diagnosis and management of systemic endemic mycoses causing pulmonar disease. Respiration, 2018, 96(3), 283-301.

http://dx.doi.org/10.1159/000489501 PMID: 29953992

[16] Kauffman, C.A. Endemic mycoses: blastomycosis, histoplasmosis, and sporotrichosis. Infect. Dis. Clin. North Am., 2006, 20(3), 645-662, vii.

http://dx.doi.org/10.1016/j.idc.2006.07.002 PMID: 16984873

[17] Colombo, A.L.; Tobón, A.; Restrepo, A.; Queiroz-Telles, F.; Nucci, M. Epidemiology of endemic systemic fungal infections in Latin America. Med. Mycol., 2011, 49(8), 785798.

http://dx.doi.org/10.3109/13693786.2011.577821 PMID: 21539506

[18] Queiroz-Telles, F.; Buccheri, R.; Benard, G. Sporotrichosis in immunicompromised hosts. J. Fungi (Basel), 2019, 5(1), $1-23$. http://dx.doi.org/10.3390/jof5010008 PMID: 30641918

[19] Magalhães, Y.C.; Bomfim, M.R.Q.; Melônio, L.C.; Ribeiro, P.C.S.; Cosme, L.M.; Rhoden, C.R.; Marques, S.G. Clinical significance of the isolation of Candida species from hospitalized patients. Braz. J. Microbiol., 2015, 46(1), 117-123. http://dx.doi.org/10.1590/S1517-838246120120296 PMID: 26221096

[20] Shirkhani, K.; Teo, I.; Armstrong-James, D.; Shaunak, S. Nebulised amphotericin B-polymethacrylic acid nanoparticle prophylaxis prevents invasive aspergillosis. Nanomedicine (Lond.), 2015, 11(5), 1217-1226.

http://dx.doi.org/10.1016/j.nano.2015.02.012 PMID: 25791815

[21] Fornari, G.; Vicente, V.A.; Gomes, R.R.; Muro, M.D.; Pinheiro, R.L.; Ferrari, C.; Herkert, P.F.; Takimura, M.; Carvalho, N.S.; Queiroz-Telles, F. Susceptibility and molecular characterization of Candida species from patients with vulvovaginitis. Braz. J. Microbiol., 2016, 47(2), 373-380. http://dx.doi.org/10.1016/j.bjm.2016.01.005 PMID: 26991298

[22] Brandolt, T.M.; Klafke, G.B.; Gonçalves, C.V.; Bitencourt, L.R.; Martinez, A.M.B.; Mendes, J.F.; Meireles, M.C.A.; Xavier, M.O. Prevalence of Candida spp. in cervicalvaginal samples and the in vitro susceptibility of isolates. Braz. J. Microbiol., 2017, 48(1), 145-150.

http://dx.doi.org/10.1016/j.bjm.2016.09.006 PMID: 27756539

[23] Fernández-García, R.; de Pablo, E.; Ballesteros, M.P.; Serrano, D.R. Unmet clinical needs in the treatment of systemic fungal infections: The role of amphotericin B and drug targeting. Int. J. Pharm., 2017, 525(1), 139-148. http://dx.doi.org/10.1016/j.ijpharm.2017.04.013 PMID: 28400291

[24] Maschmeyer, G.; Patterson, T.F. Our 2014 approach to breakthrough invasive fungal infections. Mycoses, 2014, 57(11), 645-651. http://dx.doi.org/10.1111/myc.12213 PMID: 24963554

[25] Kupferschmidt, K. New drugs target growing threat of fatal fungi. Science, 2019, 366(6464), 407.

http://dx.doi.org/10.1126/science.366.6464.407 PMID: 31649174

[26] Voltan, A.R.; Quindós, G.; Alarcón, K.P.M.; FuscoAlmeida, A.M.; Mendes-Giannini, M.J.S.; Chorilli, M. Fungal diseases: could nanostructured drug delivery systems be a novel paradigm for therapy? Int. J. Nanomedicine, 2016, 11, 3715-3730.

http://dx.doi.org/10.2147/IJN.S93105 PMID: 27540288

[27] Vásquez Marcano, R.G.D.J.; Tominaga, T.T.; Khalil, N.M.; Pedroso, L.S.; Mainardes, R.M. Chitosan functionalized poly ( $\varepsilon$-caprolactone) nanoparticles for amphotericin B delivery. Carbohydr. Polym., 2018, 202, 345-354.

http://dx.doi.org/10.1016/j.carbpol.2018.08.142 PMID: 30287009

[28] Li, H.; Wang, L.; Chai, Y.; Cao, Y.; Lu, F. Synergistic effect between silver nanoparticles and antifungal agents on Candida albicans revealed by dynamic surface-enhanced Raman spectroscopy. Nanotoxicology, 2018, 12(10), 12301240 . http://dx.doi.org/10.1080/17435390.2018.1540729 PMID: 30501538

[29] Pham, D.C.; Nguyen, T.H.; Ngoc, U.T.P.; Le, N.T.T.; Tran, T.V.; Nguyen, D.H. Preparation, characterization and antifungal properties of chitosan-silver nanoparticles synergize fungicide against Pyricularia oryzae. J. Nanosci. Nanotechnol., 2018, 18(8), 5299-5305.

http://dx.doi.org/10.1166/jnn.2018.15400 PMID: 29458580

[30] Khan, I.; Saeed, K.; Khan, I. Nanoparticles: properties, applications and toxicities. Arab. J. Chem., 2019, 12(7), 908-931.

http://dx.doi.org/10.1016/j.arabjc.2017.05.011

[31] Scheffel, U.; Rhodes, B.A.; Natarajan, T.K.; Wagner, H.N., Jr Albumin microspheres for study of the reticuloendothelial system. J. Nucl. Med., 1972, 13(7), 498-503. PMID: 5033902

[32] Athar, M.; Das, A.J. Therapeutic nanoparticles: state-of-theart of nanomedicine. Adv. Mat. Res., 2014, 1, 25-37.

[33] Barratt, G.M. Therapeutic applications of colloidal drug carriers. Pharm. Sci. Technol. Today, 2000, 3(5), 163-171. http://dx.doi.org/10.1016/S1461-5347(00)00255-8 PMID: 10785658

[34] Nilewar, G.; Mute, P.B.; Talhan, P.P.; Thakre, S. Nanocapsules: Nano novel drug delivery system. PharmaTutor, 2017, 5, 14-16.

[35] Pathak, C.; Vaidya, F.U.; Pandey, S.M. Mechanism for development of nanobased drug delivery system.Applications of Targeted Nano Drugs and Delivery Systems; Elsevier, 2019, pp. 35-67.

http://dx.doi.org/10.1016/B978-0-12-814029-1.00003-X

[36] Singh, D.; Singh, S.; Sahu, J.; Srivastava, S.; Singh, M.R. Ceramic nanoparticles: Recompense, cellular uptake and toxicity concerns. Artif. Cells Nanomed. Biotechnol., 2016, 44(1), 401-409.

http://dx.doi.org/10.3109/21691401.2014.955106 PMID: 25229834

[37] Patil, M.P.; Kim, G-D. Marine microorganisms for synthesis of metallic nanoparticles and their biomedical applications. Colloids Surf. B Biointerfaces, 2018, 172, 487-495. http://dx.doi.org/10.1016/j.colsurfb.2018.09.007 PMID: 30205339

[38] Yoon, H.Y.; Jeon, S.; You, D.G.; Park, J.H.; Kwon, I.C.; Koo, H.; Kim, K. Inorganic Nanoparticles for ImageGuided Therapy. Bioconjug. Chem., 2017, 28(1), 124-134. 
http://dx.doi.org/10.1021/acs.bioconjchem.6b00512 PMID: 27788580

[39] Chen, S.; Liu, M-X.; Yu, Y-L.; Wang, J-H. Roomtemperature synthesis of fluorescent carbon-based nanoparticles and their application in multidimensional sensing. Sens. Actuators B Chem., 2019, 288, 749-756. http://dx.doi.org/10.1016/j.snb.2019.03.067

[40] Rani, S.; Sahoo, R.K.; Nakhate, K.T.; Ajazuddin, ; Gupta, U. Biotinylated HPMA centered polymeric nanoparticles for Bortezomib delivery. Int. J. Pharm., 2020, 579119173 [published online ahead of print, $2020 \mathrm{Feb} 22$ ]. http://dx.doi.org/10.1016/j.ijpharm.2020.119173 PMID: 32097684

[41] Carvalho, I.P.S.; Miranda, M.A.; Silva, L.B.; ChrysostomoMassaro, T.N.; Paschoal, J.A.R.; Bastos, J.K.; Marcato, P.D. In vitro anticancer activity and physicochemical properties of Solanum lycocarpum alkaloidic extract loaded in natural lipid-based nanoparticles. Colloid. Interface Sci. Commun, 2019, 28, 5-14.

http://dx.doi.org/10.1016/j.colcom.2018.11.001

[42] Jeevanandam, J.; Barhoum, A.; Chan, Y.S.; Dufresne, A.; Danquah, M.K. Review on nanoparticles and nanostructured materials: history, sources, toxicity and regulations. Beilstein J. Nanotechnol., 2018, 9, 1050-1074. http://dx.doi.org/10.3762/bjnano.9.98 PMID: 29719757

[43] Wilczewska, A.Z.; Niemirowicz, K.; Markiewicz, K.H.; Car, H. Nanoparticles as drug delivery systems. Pharmacol. Rep., 2012, 64(5), 1020-1037.

http://dx.doi.org/10.1016/S1734-1140(12)70901-5 PMID: 23238461

[44] Hu, X.; Chai, Z.; Lu, L.; Ruan, H.; Wang, R.; Zhan, C. Bortezomib dendrimer prodrug-based nanoparticle system. Adv. Funct. Mater., 2019, 291807941

http://dx.doi.org/10.1002/adfm.201807941

[45] Pereverzeva, E.; Treschalin, I.; Bodyagin, D.; Maksimenko, O.; Langer, K.; Dreis, S.; Asmussen, B.; Kreuter, J.; Gelperina, S. Influence of the formulation on the tolerance profile of nanoparticle-bound doxorubicin in healthy rats: focus on cardio- and testicular toxicity. Int. J. Pharm., 2007, 337(1-2), 346-356.

http://dx.doi.org/10.1016/j.ijpharm.2007.01.031 PMID: 17306479

[46] Ray, L.; Karthik, R.; Shrivastava, V.; Singh, S. P.; Pant, A. B.; Goyal, N.; Gupta, K. C. Efficient antileishmanial activity of amphotericin B and piperine entrapped in enteric coated guar gum nanoparticles. Drug Deliv. Trans. Res., 2020.

[47] de Assis, D.N.; Araújo, R.S.; Fuscaldi, L.L.; Fernandes, S.O.A.; Mosqueira, V.C.F.; Cardoso, V.N. Biodistribution of free and encapsulated ${ }^{99 \mathrm{~m}} \mathrm{Tc}$-fluconazole in an infection model induced by Candida albicans. Biomed. Pharmacother., 2018, 99, 438-444.

http://dx.doi.org/10.1016/j.biopha.2018.01.021 PMID: 29665644

[48] Pathak, M.K.; Chhabra, G.; Pathak, K. Design and development of a novel $\mathrm{pH}$ triggered nanoemulsified in-situ ophthalmic gel of fluconazole: ex-vivo transcorneal permeation, corneal toxicity and irritation testing. Drug Dev. Ind. Pharm., 2013, 39(5), 780-790.

http://dx.doi.org/10.3109/03639045.2012.707203 PMID: 22873799

[49] Kumari, A.; Yadav, S.K.; Yadav, S.C. Biodegradable polymeric nanoparticles based drug delivery systems. Colloids Surf. B Biointerfaces, 2010, 75(1), 1-18. http://dx.doi.org/10.1016/j.colsurfb.2009.09.001 PMID: 19782542
[50] Spadari, C.C.; Lopes, L.B.; Ishida, K. Potential use of alginate-based carriers as antifungal delivery system. Front. Microbiol., 2017, 8, 97.

http://dx.doi.org/10.3389/fmicb.2017.00097 PMID 28194145

[51] George, A.; Shah, P.A.; Shrivastav, P.S. Natural biodegradable polymers based nano-formulations for drug delivery: A review. Int. J. Pharm., 2019, 561, 244-264.

http://dx.doi.org/10.1016/j.ijpharm.2019.03.011 PMID: 30851391

[52] Ren, T.; Xu, N.; Cao, C.; Yuan, W.; Yu, X.; Chen, J.; Ren, J. Preparation and therapeutic efficacy of polysorbate-80coated amphotericin B/PLA-b-PEG nanoparticles. J. Biomater. Sci. Polym. Ed., 2009, 20(10), 1369-1380. http://dx.doi.org/10.1163/092050609X12457418779185 PMID: 19622277

[53] Sinha, B.; Mukherjee, B.; Pattnaik, G. Poly-lactide-coglycolide nanoparticles containing voriconazole for pulmonary delivery: in vitro and in vivo study. Nanomedicine (Lond.), 2013, 9(1), 94-104.

http://dx.doi.org/10.1016/j.nano.2012.04.005 PMID: 22633899

[54] Kumar, R.; Sinha, V.R. Fabrication of voriconazol solid lipid nanoparticle for effective ocular delivery. Value Health, 2014, 17, 613.

http://dx.doi.org/10.1016/j.jval.2014.08.2153

[55] Santos, R.S.; Loureiro, K.; Rezende, P.; Nalone, L.; Barbosa, R.M.; Santini, A.; Santos, A.C.; Silva, C.F.; Souto, E.B.; Souza, D.P.; Amaral, R.G.; Severino, P. Innovative nanocompounds for cutaneous administration of classical antifungal drugs: a systematic review. J. Dermatolog. Treat., 2018, 1, 1-37.

PMID: 29856232

[56] Czajkowska-Kośnik, A.; Szekalska, M.; Winnicka, K. Nanostructured lipid carriers: A potential use for skin drug delivery systems. Pharmacol. Rep., 2019, 71(1), 156-166. http://dx.doi.org/10.1016/j.pharep.2018.10.008 PMID: 30550996

[57] Ruttala, H.B.; Ramasamy, T.; Madeshwaran, T.; Hiep, T.T.; Kandasamy, U.; Oh, K.T.; Choi, H.G.; Yong, C.S.; Kim, J.O. Emerging potential of stimulus-responsive nanosized anticancer drug delivery systems for systemic applications. Arch. Pharm. Res., 2018, 41(2), 111-129.

http://dx.doi.org/10.1007/s12272-017-0995-x PMID: 29214601

[58] Rao, J.P.; Geckeler, K.E. Polymer nanoparticles: preparation techniques and size-control parameters. Prog. Polym. Sci., 2011, 36, 887-913.

http://dx.doi.org/10.1016/j.progpolymsci.2011.01.001

[59] Stella, B.; Marengo, A.; Arpicco, S. Nanoparticles: an overview of the preparation methods from preformed polymers; Istituto Lombardo - Accademia Di Scienze e Lettere Incontri Di Studio, 2017.

[60] Albernaz, V.L.; Bach, M.; Weber, A.; Southan, A.; Tovar, G.E.M. Active ester containing surfmer for one-stage polymer nanoparticle surface functionalization in mini-emulsion polymerization. Polymers (Basel), 2018, 10(4), 408. http://dx.doi.org/10.3390/polym10040408 PMID: 30966443

[61] Liu, B.; Fu, Z.; Meng, W.; Chen, M.; Wu, G.; Zhang, M.; Zhang, H. New insights on in situ charge neutralization governing particle size distribution in macroemulsion polymerization. Colloids Surf. A Physicochem. Eng. Asp., 2018, 540, 242-248.

http://dx.doi.org/10.1016/j.colsurfa.2018.01.020

[62] Inagaki, C.S.; Oliveira, M.M.; Zarbin, A.J.G. Direct and one-step synthesis of polythiophene/gold nanoparticles thin 
films through liquid/liquid interfacial polymerization. $J$. Colloid Interface Sci., 2018, 516, 498-510.

http://dx.doi.org/10.1016/j.jcis.2018.01.076 PMID: 29408140

[63] Desgouilles, S.; Vauthier, C.; Bazile, D.; Vacus, J.; Grossiord, J-L.; Veillard, M.; Couvreur, P. The design of nanoparticles obtained by solvent evaporation: a comprehensive study. Langmuir, 2003, 19, 9504-9510.

http://dx.doi.org/10.1021/la034999q

[64] Deng, Y.; Yang, F.; Zhao, X.; Wang, L.; Wu, W.; Zu, C.; $\mathrm{Wu}, \mathrm{M}$. Improving the skin penetration and antifebrile activity of ibuprofen by preparing nanoparticles using emulsion solvent evaporation method. Eur. J. Pharm. Sci., 2018, 114, 293-302.

http://dx.doi.org/10.1016/j.ejps.2017.12.024 PMID: 29288707

[65] Tarhini, M.; Benlyamani, I.; Hamdani, S.; Agusti, G.; Fessi, H.; Greige-Gerges, H.; Bentaher, A.; Elaissari, A. Proteinbased nanoparticle preparation via nanoprecipitation method. Materials (Basel), 2018, 11(3), 394.

http://dx.doi.org/10.3390/ma1 1030394 PMID: 29518919

[66] Esmaeili, F.; Atyabi, F.; Dinarvand, R. Preparation and characterization of estradiol-loaded PLGA nanoparticles using homogenization-solvent diffusion method. Daru, 2008, 16, 196-202.

[67] Iqbal, M.; Zafar, N.; Fessi, H.; Elaissari, A. Double emulsion solvent evaporation techniques used for drug encapsulation. Int. J. Pharm., 2015, 496(2), 173-190. http://dx.doi.org/10.1016/j.ijpharm.2015.10.057 PMID: 26522982

[68] Martinez, N.Y.; Andrade, P.F.; Durán, N.; Cavalitto, S. Development of double emulsion nanoparticles for the encapsulation of bovine serum albumin. Colloids Surf. B Biointerfaces, 2017, 158, 190-196.

http://dx.doi.org/10.1016/j.colsurfb.2017.06.033 PMID: 28692874

[69] Nah, J-W.; Paek, Y-W.; Jeong, Y-I.; Kim, D-W.; Cho, C-S.; Kim, S-H.; Kim, M-Y. Clonazepam release from poly(DLlactide-co-glycolide) nanoparticles prepared by dialysis method. Arch. Pharm. Res., 1998, 21(4), 418-422. http://dx.doi.org/10.1007/BF02974636 PMID: 9875469

[70] Wong, T.W.; John, P. Advances in spray drying technology for nanoparticle formation.Handbook of Nanoparticles; Aliofkhazraei, M., Ed.; Springer: Cham, 2015, pp. 329-346. http://dx.doi.org/10.1007/978-3-319-13188-7_18-1

[71] Montes, A.; Gordillo, M.D.; Pereyra, C.; Martinez de la Ossa, E.J. Particles formation using supercritical fluids.Mass Transfer - Advanced Aspects; Nakajima, H., Ed.; InTech, 2011, pp. 461-80.

http://dx.doi.org/10.5772/21271

[72] Saad, W.S.; Prud'homme, R.K. Principles of nanoparticle formation by flash nanoprecipitation. Nano Today, 2016, 11, 212-227.

http://dx.doi.org/10.1016/j.nantod.2016.04.006

[73] Pant, A.; Negi, J.S. Novel controlled ionic gelation strategy for chitosan nanoparticles preparation using TPP- $\beta$-CD inclusion complex. Eur. J. Pharm. Sci., 2018, 112, 180-185. http://dx.doi.org/10.1016/j.ejps.2017.11.020 PMID: 29191520

[74] Helttunen, K.; Galán, A.; Ballester, P.; Bergenholtz, J.; Nissinen, M. Solid lipid nanoparticles from amphiphilic calixpyrroles. J. Colloid Interface Sci., 2016, 464, 59-65. http://dx.doi.org/10.1016/j.jcis.2015.11.012 PMID: 26609923

[75] Amasya, G.; Aksu, B.; Badilli, U.; Onay-Besikci, A.; Tarimci, N. QbD guided early pharmaceutical development study: Production of lipid nanoparticles by high pressure homogenization for skin cancer treatment. Int. J. Pharm., 2019, 563, 110-121.

http://dx.doi.org/10.1016/j.ijpharm.2019.03.056 PMID: 30935913

[76] Mendes, A.I.; Silva, A.C.; Catita, J.A.; Cerqueira, F.; Gabriel, C.; Lopes, C.M. Miconazole-loaded nanostructured lipid carriers (NLC) for local delivery to the oral mucosa: improving antifungal activity. Colloids Surf. B Biointerfaces, 2013, 111, 755-763.

http://dx.doi.org/10.1016/j.colsurfb.2013.05.041 PMID: 23954816

[77] Kotler-Brajtburg, J.; Price, H.D.; Medoff, G.; Schlessinger, D.; Kobayashi, G.S. Molecular basis for the selective toxicity of amphotericin B for yeast and filipin for animal cells. Antimicrob. Agents Chemother., 1974, 5(4), 377-382.

http://dx.doi.org/10.1128/AAC.5.4.377 PMID: 15825391

[78] Scorzoni, L.; de Paula E Silva, A.C.; Marcos, C.M.; Assato, P.A.; de Melo, W.C.; de Oliveira, H.C.; Costa-Orlandi, C.B.; Mendes-Giannini, M.J.; Fusco-Almeida, A.M. Antifungal therapy: new advances in the understanding and treatment of mycosis. Front. Microbiol., 2017, 8, 36. http://dx.doi.org/10.3389/fmicb.2017.00036 PMID: 28167935

[79] Anderson, T.M.; Clay, M.C.; Cioffi, A.G.; Diaz, K.A.; Hisao, G.S.; Tuttle, M.D.; Nieuwkoop, A.J.; Comellas, G.; Maryum, N.; Wang, S.; Uno, B.E.; Wildeman, E.L.; Gonen, T.; Rienstra, C.M.; Burke, M.D. Amphotericin forms an extramembranous and fungicidal sterol sponge. Nat. Chem. Biol., 2014, 10(5), 400-406.

http://dx.doi.org/10.1038/nchembio.1496 PMID: 24681535

[80] Bolard, J. How do the polyene macrolide antibiotics affect the cellular membrane properties? Biochim. Biophys. Acta, 1986, 864(3-4), 257-304.

http://dx.doi.org/10.1016/0304-4157(86)90002-X PMID: 3539192

[81] Holz, R.W. The effects of the polyene antibiotics nystatin and amphotericin B on thin lipid membranes. Ann. N. Y. Acad. Sci., 1974, 235(0), 469-479.

http://dx.doi.org/10.1111/j.1749-6632.1974.tb43284.x PMID: 4528030

[82] Jukic, E.; Blatzer, M.; Posch, W.; Steger, M.; Binder, U.; Lass-Flörl, C.; Wilflingseder, D. Oxidative stress response tips the balance in Aspergillus terreus amphotericin B resistance. Antimicrob. Agents Chemother., 2017, 61(10), 1-14. http://dx.doi.org/10.1128/AAC.00670-17 PMID: 28739793

[83] Vriens, K.; Kumar, P.T.; Struyfs, C.; Cools, T.L.; Spincemaille, P.; Kokalj, T.; Sampaio-Marques, B.; Ludovico, P.; Lammertyn, J.; Cammue, B.P.A.; Thevissen, K. Increasing the fungicidal action of amphotericin B by inhibiting the nitric oxide-dependent tolerance pathway. Oxid. Med. Cell. Longev., 2017, 20174064628 http://dx.doi.org/10.1155/2017/4064628 PMID: 29129987

[84] Jambor, W.P.; Steinberg, B.A.; Suydam, L.O. Amphotericins $\mathrm{A}$ and $\mathrm{B}$ : two new antifungal antibiotics possessing high activity against deep-seated and superficial mycoses. Antibiot. Annu., 1955-1956, 3, 574-578. PMID: 13355329

[85] Caffrey, P.; Lynch, S.; Flood, E.; Finnan, S.; Oliynyk, M. Amphotericin biosynthesis in Streptomyces nodosus: deductions from analysis of polyketide synthase and late genes. Chem. Biol., 2001, 8(7), 713-723.

http://dx.doi.org/10.1016/S1074-5521(01)00046-1 PMID: 11451671 
[86] Odds, F.C.; Brown, A.J.; Gow, N.A. Antifungal agents: mechanisms of action. Trends Microbiol., 2003, 11(6), 272279.

http://dx.doi.org/10.1016/S0966-842X(03)00117-3 PMID: 12823944

[87] Silva, A.E.; Barratt, G.; Chéron, M.; Egito, E.S. Development of oil-in-water microemulsions for the oral delivery of amphotericin B. Int. J. Pharm., 2013, 454(2), 641-648. http://dx.doi.org/10.1016/j.ijpharm.2013.05.044 PMID: 23726904

[88] Halperin, A.; Shadkchan, Y.; Pisarevsky, E.; Szpilman, A.M.; Sandovsky, H.; Osherov, N.; Benhar, I. Novel watersoluble amphotericin B-PEG conjugates with low toxicity and potent in vivo efficacy. J. Med. Chem., 2016, 59(3), 1197-1206.

http://dx.doi.org/10.1021/acs.jmedchem.5b01862 PMID: 26816333

[89] Ling, J.T.S.; Roberts, C.J.; Billa, N. Antifungal and mucoadhesive properties of an orally administered chitosancoated amphotericin B nanostructured lipid carrier (NLC). AAPS PharmSciTech, 2019, 20(3), 136.

http://dx.doi.org/10.1208/s12249-019-1346-7 PMID: 30838459

[90] Krishnan, R.A.; Pant, T.; Sankaranarayan, S.; Stenberg, J.; Jain, R.; Dandekar, P. Protective nature of low molecular weight chitosan in a chitosan-Amphotericin B nanocomplex - A physicochemical study. Mater. Sci. Eng. C, 2018, 93, 472-482.

http://dx.doi.org/10.1016/j.msec.2018.08.016 PMID: 30274080

[91] Senna, J.P.; Barradas, T.N.; Cardoso, S.; Castiglione, T.C.; Serpe, M.J.; Silva, K.G.H.E.; Mansur, C.R.E. Dual alginatelipid nanocarriers as oral delivery systems for amphotericin B. Colloids Surf. B Biointerfaces, 2018, 166, 187-194. http://dx.doi.org/10.1016/j.colsurfb.2018.03.015 PMID: 29602077

[92] Azanza, J.R.; Sádada, B.; Reis, J. Liposomal formulations of amphotericin B: differences according to the scientific evidence. Rev. Esp. Quimioter., 2015, 28(6), 275-281. PMID: 26621170

[93] Rivnay, B.; Wakim, J.; Avery, K.; Petrochenko, P.; Myung, J.H.; Kozak, D.; Yoon, S.; Landrau, N.; Nivorozhkin, A. Critical process parameters in manufacturing of liposomal formulations of amphotericin B. Int. J. Pharm., 2019, 565, 447-457.

http://dx.doi.org/10.1016/j.ijpharm.2019.04.052 PMID: 31071418

[94] Aversa, F.; Busca, A.; Candoni, A.; Cesaro, S.; Girmenia, C.; Luppi, M.; Nosari, A.M.; Pagano, L.; Romani, L.; Rossi, G.; Venditti, A.; Novelli, A. Liposomal amphotericin $\mathrm{B}\left(\right.$ AmBisome $\left.{ }^{\circledR}\right)$ at beginning of its third decade of clinical use. J. Chemother., 2017, 29(3), 131-143.

http://dx.doi.org/10.1080/1120009X.2017.1306183 PMID: 28335692

[95] Bekersky, I.; Fielding, R.M.; Dressler, D.E.; Lee, J.W.; Buell, D.N.; Walsh, T.J. Plasma protein binding of amphotericin $\mathrm{B}$ and pharmacokinetics of bound versus unbound amphotericin B after administration of intravenous liposomal amphotericin B (AmBisome) and amphotericin B deoxycholate. Antimicrob. Agents Chemother., 2002, 46(3), 834-840.

http://dx.doi.org/10.1128/AAC.46.3.834-840.2002 PMID: 11850269

[96] Collette, N.; van der Auwera, P.; Lopez, A.P.; Heymans, C.; Meunier, F. Tissue concentrations and bioactivity of amphotericin B in cancer patients treated with amphotericin
B-deoxycholate. Antimicrob. Agents Chemother., 1989, 33(3), 362-368.

http://dx.doi.org/10.1128/AAC.33.3.362 PMID: 2658785

[97] Atkinson, A.J., Jr; Bennett, J.E. Amphotericin B pharmacokinetics in humans. Antimicrob. Agents Chemother., 1978, 13(2), 271-276. http://dx.doi.org/10.1128/AAC.13.2.271 PMID: 646348

[98] Goodwin, S.D.; Cleary, J.D.; Walawander, C.A.; Taylor, J.W.; Grasela, T.H.J., Jr Pretreatment regimens for adverse events related to infusion of amphotericin B. Clin. Infect. Dis., 1995, 20(4), 755-761.

http://dx.doi.org/10.1093/clinids/20.4.755 PMID: 7795069

[99] Cleary, J.D.; Rogers, P.D.; Chapman, S.W. Variability in polyene content and cellular toxicity among deoxycholate amphotericin B formulations. Pharmacotherapy, 2003, 23(5), 572-578.

http://dx.doi.org/10.1592/phco.23.5.572.32209 PMID: 12741430

[100] Mathpal, D.; Garg, T.; Rath, G.; Goyal, A.K. Development and characterization of spray dried microparticles for pulmonary delivery of antifungal drug. Curr. Drug Deliv., 2015, 12(4), 464-471.

http://dx.doi.org/10.2174/1567201812666150326110821 PMID: 25808185

[101] Jansook, P.; Fülöp, Z.; Ritthidej, G.C. Amphotericin B loaded solid lipid nanoparticles (SLNs) and nanostructured lipid carrier (NLCs): physicochemical and solid-solution state characterizations. Drug Dev. Ind. Pharm., 2019, 45(4), 560-567.

http://dx.doi.org/10.1080/03639045.2019.1569023 PMID: 30632399

[102] Kaur, I.P.; Kakkar, S. Topical delivery of antifungal agents. Expert Opin. Drug Deliv., 2010, 7(11), 1303-1327. http://dx.doi.org/10.1517/17425247.2010.525230 PMID: 20961206

[103] Bodin, M.B.; Godoy, G.; Philips, J.B., III Topical nystatin for the prevention of catheter-associated candidiasis in ELBW infants. Adv. Neonatal Care, 2015, 15(3), 220-224. http://dx.doi.org/10.1097/ANC.0000000000000170 PMID: 25938952

[104] Samaranayake, L.P.; Keung Leung, W.; Jin, L. Oral mucosal fungal infections. Periodontol. 2000, 2009, 49, 39-59. http://dx.doi.org/10.1111/j.1600-0757.2008.00291.x PMID: 19152525

[105] Razonable, R.R.; Henault, M.; Watson, H.L.; Paya, C.V. Nystatin induces secretion of interleukin (IL)-1 $\beta$, IL-8, and tumor necrosis factor alpha by a toll-like receptordependent mechanism. Antimicrob. Agents Chemother., 2005, 49(8), 3546-3549.

http://dx.doi.org/10.1128/AAC.49.8.3546-3549.2005 PMID: 16048981

[106] Greene, C.; Jones, R.; Hollis, L. Biopsticides registration action document: natamycin; Enviromental Protection Agency: United States, 2012. https://www3.epa.gov/pesticides/chem_search/reg_actions/r egistration/decision_PC-051102_14-May-12.pdf

[107] Rosa, P.D.; Sheid, K.; Locatelli, C.; Marinho, D.; Goldani, L. Fusarium solani keratitis: role of antifungal susceptibility testing and identification to the species level for proper management. Braz. J. Infect. Dis., 2019, 23(3), 197-199. http://dx.doi.org/10.1016/j.bjid.2019.05.002 PMID: 31129063

[108] Garnier, L.; Mounier, J.; Lê, S.; Pawtowski, A.; Pinon, N.; Camier, B.; Chatel, M.; Garric, G.; Thierry, A.; Coton, E.; Valence, F. Development of antifungal ingredients for dairy 
products: From in vitro screening to pilot scale application. Food Microbiol., 2019, 81, 97-107. http://dx.doi.org/10.1016/j.fm.2018.11.003 PMID: 30910092

[109] Jain, A.; Shah, S.G.; Chugh, A. Cell penetrating peptides as efficient nanocarriers for delivery of antifungal compound, natamycin for the treatment of fungal keratitis. Pharm. Res., 2015, 32(6), 1920-1930.

http://dx.doi.org/10.1007/s11095-014-1586-x PMID: 25467959

[110] Kovačević, N.; Kokalj, A. DFT Study of interaction of azoles with $\mathrm{Cu}(111)$ and $\mathrm{Al}(111)$ surfaces: role of azole nitrogen atoms and dipole-dipole interactions. J. Phys. Chem. C, 2011, 115, 24189-24197. http://dx.doi.org/10.1021/jp207076w

[111] Vanden Bossche, H.; Marichal, P.; Odds, F.C. Molecular mechanisms of drug resistance in fungi. Trends Microbiol., 1994, 2(10), 393-400.

http://dx.doi.org/10.1016/0966-842X(94)90618-1 PMID: 7850208

[112] Ha, K.C.; White, T.C. Effects of azole antifungal drugs on the transition from yeast cells to hyphae in susceptible and resistant isolates of the pathogenic yeast Candida albicans. Antimicrob. Agents Chemother., 1999, 43(4), 763-768. http://dx.doi.org/10.1128/AAC.43.4.763 PMID: 10103178

[113] Kauffman, C.A.; Pappas, P.G.; McKinsey, D.S.; Greenfield, R.A.; Perfect, J.R.; Cloud, G.A.; Thomas, C.J.; Dismukes, W.E. Treatment of lymphocutaneous and visceral sporotrichosis with fluconazole. Clin. Infect. Dis., 1996, 22(1), 46-50.

http://dx.doi.org/10.1093/clinids/22.1.46 PMID: 8824965

[114] Carrillo-Muñoz, A.J.; Quindós, G.; Tur, C.; Ruesga, M.; Alonso, R.; del Valle, O.; Rodriguez, V.; Arévalo, M.P.; Salgado, J.; Martin-Mazuelos, E.; Bornay-Llinares, F.J.; del Palacio, A.; Cuétara, M.; Gasser, I.; Hernández-Molina, J.M.; Pemán, J. Comparative in vitro antifungal activity of amphotericin B lipid complex, amphotericin B and fluconazole. Chemotherapy, 2000, 46(4), 235-244. http://dx.doi.org/10.1159/000007295 PMID: 10859429

[115] Sholam, S.; Groll, A.H.; Petraitis, V.; Walsh, T.J. Systemic antifungal agents. Infect. Dis., 2017, 2, 1333-1344.

[116] Arndt, C.A.; Walsh, T.J.; McCully, C.L.; Balis, F.M.; Pizzo, P.A.; Poplack, D.G. Fluconazole penetration into cerebrospinal fluid: implications for treating fungal infections of the central nervous system. J. Infect. Dis., 1988, 157(1), 178-180.

http://dx.doi.org/10.1093/infdis/157.1.178 PMID: 2826606

[117] Perry, C.M.; Whittington, R.; McTavish, D. Fluconazole. An update of its antimicrobial activity, pharmacokinetic properties, and therapeutic use in vaginal candidiasis. Drugs, 1995, 49(6), 984-1006.

http://dx.doi.org/10.2165/00003495-199549060-00009 PMID: 7641607

[118] Uchida, K.; Shimogawara, K.; Yamaguchi, H. Correlation of in vitro activity and in vivo efficacy of itraconazole intravenous and oral solubilized formulations by testing Candida strains with various itraconazole susceptibilities in a murine invasive infection. J. Antimicrob. Chemother., 2011, 66(3), 626-634.

http://dx.doi.org/10.1093/jac/dkq475 PMID: 21172782

[119] Poirier, J.M.; Cheymol, G. Optimisation of itraconazole therapy using target drug concentrations. Clin. Pharmacokinet., 1998, 35(6), 461-473.

http://dx.doi.org/10.2165/00003088-199835060-00004 PMID: 9884817
[120] Domínguez-Gil Hurlé, A.; Sánchez Navarro, A.; Garcia Sanchez, M.J. Therapeutic drug monitoring of itraconazole and the relevance of pharmacokinetic interactions. Clin. Microbiol. Infect., 2006, 12, 97-106.

http://dx.doi.org/10.1111/j.1469-0691.2006.01611.x

[121] Heykants, J.; Van Peer, A.; Van de Velde, V.; Van Rooy, P.; Meuldermans, W.; Lavrijsen, K.; Woestenborghs, R.; Van Cutsem, J.; Cauwenbergh, G. The clinical pharmacokinetics of itraconazole: an overview. Mycoses, 1989, 32(Suppl. 1), 67-87.

http://dx.doi.org/10.1111/j.1439-0507.1989.tb02296.x PMID: 2561187

[122] Akhtar, S.; Masood, S.; Tabassum, S.; Rizvi, D.A. Efficacy of itraconazole versus fluconazole in vaginal candidiasis. $J$. Pak. Med. Assoc., 2012, 62(10), 1049-1052. PMID: 23866445

[123] Jennings, T.S.; Hardin, T.C. Treatment of aspergillosis with itraconazole. Ann. Pharmacother., 1993, 27(10), 12061211. http://dx.doi.org/10.1177/106002809302701011 PMID: 8251691

[124] Sabatelli, F.; Patel, R.; Mann, P.A.; Mendrick, C.A.; Norris, C.C.; Hare, R.; Loebenberg, D.; Black, T.A.; McNicholas, P.M. In vitro activities of posaconazole, fluconazole, itraconazole, voriconazole, and amphotericin B against a large collection of clinically important molds and yeasts. Antimicrob. Agents Chemother., 2006, 50(6), 2009-2015. http://dx.doi.org/10.1128/AAC.00163-06 PMID: 16723559

[125] Borman, A.M.; Fraser, M.; Palmer, M.D.; Szekely, A.; Houldsworth, M.; Patterson, Z.; Johnson, E.M. MIC Distributions and evaluation of fungicidal activity for amphotericin B, itraconazole, voriconazole, posaconazole and caspofungin and 20 species of pathogenic filamentous fungi determined using the CLSI broth microdilution method. $J$. Fungi (Basel), 2017, 3(2), 27. http://dx.doi.org/10.3390/jof3020027 PMID: 29371545

[126] Johnson, E.M.; Szekely, A.; Warnock, D.W. In-vitro activity of voriconazole, itraconazole and amphotericin B against filamentous fungi. J. Antimicrob. Chemother., 1998, 42(6), 741-745.

http://dx.doi.org/10.1093/jac/42.6.741 PMID: 10052897

[127] Miller, D.A.; DiNunzio, J.C.; Yang, W.; McGinity, J.W.; Williams, R.O., III Enhanced in vivo absorption of itraconazole via stabilization of supersaturation following acidic-toneutral pH transition. Drug Dev. Ind. Pharm., 2008, 34(8), 890-902.

http://dx.doi.org/10.1080/03639040801929273 PMID: 18608468

[128] Brüggemann, R.J.M.; Alffenaar, J.W.C.; Blijlevens, N.M.A.; Billaud, E.M.; Kosterink, J.G.W.; Verweij, P.E.; Burger, D.M.; Saravolatz, L.D. Clinical relevance of the pharmacokinetic interactions of azole antifungal drugs with other coadministered agents. Clin. Infect. Dis., 2009, 48(10), 1441-1458.

http://dx.doi.org/10.1086/598327 PMID: 19361301

[129] Pfaller, M.A.; Messer, S.A.; Boyken, L.; Hollis, R.J.; Rice, C.; Tendolkar, S.; Diekema, D.J. In vitro activities of voriconazole, posaconazole, and fluconazole against 4,169 clinical isolates of Candida spp. and Cryptococcus neoformans collected during 2001 and 2002 in the ARTEMIS global antifungal surveillance program. Diagn. Microbiol. Infect. Dis., 2004, 48(3), 201-205.

http://dx.doi.org/10.1016/j.diagmicrobio.2003.09.008 PMID: 15023430

[130] Patterson, T.F.; Thompson, G.R.; Denning, D.W.; Fishman, J.A.; Hadley, S.; Herbrecht, R.; Kontpyiannis, D.P.; Marr, 
K.A.; Morrison, V.A.; Segal, M.H.N.B.H.; Steinbach, W.J.; Stevens, D.A.; Walsh, T.J.; Wingard, J.R.; Young, J.H.; Bennett, J.E. Practice guidelines for the diagnosis and management of aspergillosis: 2016 Update by the Infectious Diseases Society of America. Clin. Infect. Dis., 2016, 63, 160.

http://dx.doi.org/10.1093/cid/ciw326

[131] Maertens, J.A. History of the development of azole derivatives. Clin. Microbiol. Infect., 2004, 10(Suppl. 1), 1-10. http://dx.doi.org/10.1111/j.1470-9465.2004.00841.x PMID: 14748798

[132] Espinel-Ingroff, A.; Boyle, K.; Sheehan, D.J. In vitro antifungal activities of voriconazole and reference agents as determined by NCCLS methods: review of the literature. $M y$ copathologia, 2001, 150(3), 101-115.

http://dx.doi.org/10.1023/A:1010954803886 PMID: 11469757

[133] Purkins, L.; Wood, N.; Greenhalgh, K.; Allen, M.J.; Oliver, S.D. Voriconazole, a novel wide-spectrum triazole: oral pharmacokinetics and safety. Br. J. Clin. Pharmacol., 2003, 56(Suppl. 1), 10-16.

http://dx.doi.org/10.1046/j.1365-2125.2003.01993.x PMID: 14616408

[134] Slain, D.; Rogers, P.D.; Cleary, J.D.; Chapman, S.W. Intravenous itraconazole. Ann. Pharmacother., 2001, 35(6), 720729.

http://dx.doi.org/10.1345/aph.10262 PMID: 11408991

[135] Hyland, R.; Jones, B.C.; Smith, D.A. Identification of the cytochrome P450 enzymes involved in the N-oxidation of voriconazole. Drug Metab. Dispos., 2003, 31(5), 540-547. http://dx.doi.org/10.1124/dmd.31.5.540 PMID: 12695341

[136] Krishna, G.; Moton, A.; Ma, L.; Medlock, M.M.; McLeod, J. Pharmacokinetics and absorption of posaconazole oral suspension under various gastric conditions in healthy volunteers. Antimicrob. Agents Chemother., 2009, 53(3), 958966.

http://dx.doi.org/10.1128/AAC.01034-08 PMID: 19075045

[137] Wexler, D.; Courtney, R.; Richards, W.; Banfield, C.; Lim, J.; Laughlin, M. Effect of posaconazole on cytochrome P450 enzymes: a randomized, open-label, two-way crossover study. Eur. J. Pharm. Sci., 2004, 21(5), 645-653. http://dx.doi.org/10.1016/j.ejps.2004.01.005 PMID: 15066665

[138] Dolton, M.J.; Ray, J.E.; Chen, S.C.A.; Ng, K.; Pont, L.; McLachlan, A.J. Multicenter study of posaconazole therapeutic drug monitoring: exposure-response relationship and factors affecting concentration. Antimicrob. Agents Chemother., 2012, 56(11), 5503-5510.

http://dx.doi.org/10.1128/AAC.00802-12 PMID: 22890761

[139] Krieter, P.; Flannery, B.; Musick, T.; Gohdes, M.; Martinho, M.; Courtney, R. Disposition of posaconazole following single-dose oral administration in healthy subjects. $A n-$ timicrob. Agents Chemother., 2004, 48(9), 3543-3551. http://dx.doi.org/10.1128/AAC.48.9.3543-3551.2004 PMID: 15328123

[140] Odds, F.C.; Milne, L.J.; Gentles, J.C.; Ball, E.H. The activity in vitro and in vivo of a new imidazole antifungal, ketoconazole. J. Antimicrob. Chemother., 1980, 6(1), 97-104. http://dx.doi.org/10.1093/jac/6.1.97 PMID: 6244258

[141] Gupta, A.K.; Lyons, D.C.A. The rise and fall of oral ketoconazole. J. Cutan. Med. Surg., 2015, 19(4), 352-357. http://dx.doi.org/10.1177/1203475415574970 PMID: 25775613

[142] Limits usage of nizoral (ketoconazole) oral tablets due to potentially fatal liver injury and risk of drug interactions and adrenal gland problems. FDA Drug Safety Communica- tion.,

http://www.fda.gov/drugs/drugsafety/ucm3624152019.

[143] Kim, J.H.; Choi, W.G.; Lee, S.; Lee, H.S. Revisiting the metabolism and bioativation of ketoconazole in human and mouse using liquid chromatography-mass spectrometrybased metabolomics. Int. J. Mol. Sci., 2017, 18, 621. http://dx.doi.org/10.3390/ijms18030621

[144] Sagir, A.; Schmitt, M.; Dilger, K.; Häussinger, D. Inhibition of cytochrome P450 3A: relevant drug interactions in gastroenterology. Digestion, 2003, 68(1), 41-48.

http://dx.doi.org/10.1159/000073224 PMID: 12949438

[145] Ning, M.; Gu, Z.; Pan, H.; Yu, H.; Xiao, K. Preparation and in vitro evaluation of liposomal/niosomal delivery systems for antifungal drug clotrimazole. Indian J. Exp. Biol., 2005, 43(2), 150-157.

PMID: 15782815

[146] Sawyer, P.R.; Brogden, R.N.; Pinder, R.M.; Speight, T.M.; Avery, G.S. Clotrimazole: a review of its antifungal activity and therapeutic efficacy. Drugs, 1975, 9(6), 424-447. http://dx.doi.org/10.2165/00003495-197509060-00003 PMID: 1097234

[147] Chang, C.C.; Slavin, M.A.; Chen, S.C. New developments and directions in the clinical application of the echinocandins. Arch. Toxicol., 2017, 91(4), 1613-1621. http://dx.doi.org/10.1007/s00204-016-1916-3 PMID: 28180946

[148] Patil, A.; Majumdar, S. Echinocandins in antifungal pharmacotherapy. J. Pharm. Pharmacol., 2017, 69(12), 16351660 . http://dx.doi.org/10.1111/jphp.12780 PMID: 28744860

[149] Grover, N.D. Echinocandins: A ray of hope in antifungal drug therapy. Indian J. Pharmacol., 2010, 42(1), 9-11. http://dx.doi.org/10.4103/0253-7613.62396 PMID: 20606829

[150] Azanza Perea, J.R. [Echinocandins: Applied pharmacology]. Rev. Iberoam. Micol., 2016, 33(3), 140-144. http://dx.doi.org/10.1016/j.riam.2016.02.004 PMID: 27395024

[151] Ben-Ami, R. Treatment of invasive candidiasis: A narrative review. J. Fungi (Basel), 2018, 4(3), 97. http://dx.doi.org/10.3390/jof4030097 PMID: 30115843

[152] Develoux, M. [Griseofulvin]. Ann. Dermatol. Venereol., 2001, 128(12), 1317-1325. PMID: 11908134

[153] Chandra, J.; Ghannoum, M.A. Flucytosine treatment and resistance mechanisms; Antimicrob. Drug. Resist, 2009, pp. 407-413.

[154] Polak, A.; Grenson, M. Evidence for a common transport system for cytosine, adenine and hypoxanthine in Saccharomyces cerevisiae and Candida albicans. Eur. J. Biochem., 1973, 32(2), 276-282.

http://dx.doi.org/10.1111/j.1432-1033.1973.tb02608.x PMID: 4569075

[155] Cutler, R.E.; Blair, A.D.; Kelly, M.R. Flucytosine kinetics in subjects with normal and impaired renal function. Clin. Pharmacol. Ther., 1978, 24(3), 333-342. http://dx.doi.org/10.1002/cpt1978243333 PMID: 688726

[156] Francis, P.; Walsh, T.J. Evolving role of flucytosine in immunocompromised patients: new insights into safety, pharmacokinetics, and antifungal therapy. Clin. Infect. Dis., 1992, 15(6), 1003-1018. http://dx.doi.org/10.1093/clind/15.6.1003 PMID: 1457631

[157] Bennet, J.E. Flucytosine. Ann. Intern. Med., 1977, 86(3), 319-321.

http://dx.doi.org/10.7326/0003-4819-86-3-319 PMID: 320931 
[158] Denning, D.W.; Stevens, D.A. Antifungal and surgical treatment of invasive aspergillosis: review of 2,121 published cases. Rev. Infect. Dis., 1990, 12(6), 1147-1201. http://dx.doi.org/10.1093/clinids/12.6.1147 PMID: 2267490

[159] Lewis, R.E. Current concepts in antifungal pharmacology. Mayo Clin. Proc., 2011, 86(8), 805-817. http://dx.doi.org/10.4065/mcp.2011.0247 PMID: 21803962

[160] Soliman, G.M. Nanoparticles as safe and effective delivery systems of antifungal agents: Achievements and challenges. Int. J. Pharm., 2017, 523(1), 15-32.

http://dx.doi.org/10.1016/j.ijpharm.2017.03.019 PMID: 28323096

[161] Zhang, L.; Pornpattananangku, D.; Hu, C.M.; Huang, C.M. Development of nanoparticles for antimicrobial drug delivery. Curr. Med. Chem., 2010, 17(6), 585-594. http://dx.doi.org/10.2174/092986710790416290 PMID: 20015030

[162] Ghannoum, M.A.; Rice, L.B. Antifungal agents: mode of action, mechanisms of resistance, and correlation of these mechanisms with bacterial resistance. Clin. Microbiol. Rev., 1999, 12(4), 501-517.

http://dx.doi.org/10.1128/CMR.12.4.501 PMID: 10515900

[163] Lee, H.; Lee, D.G. Novel approaches for efficient antifungal drug action. J. Microbiol. Biotechnol., 2018, 28(11), 1771-1781.

http://dx.doi.org/10.4014/jmb.1807.07002 PMID: 30178649

[164] Tverdek, F.P.; Kofteridis, D.; Kontoyiannis, D.P. Antifungal agents and liver toxicity: a complex interaction. Expert Rev. Anti Infect. Ther., 2016, 14(8), 765-776.

http://dx.doi.org/10.1080/14787210.2016.1199272 PMID: 27275514

[165] Amigues, I.; Cohen, N.; Chung, D.; Seo, S.K.; Plescia, C.; Jakubowski, A.; Barker, J.; Papanicolaou, G.A. Hepatic safety of voriconazole after allogeneic hematopoietic stem cell transplantation. Biol. Blood Marrow Transplant., 2010, 16(1), 46-52.

http://dx.doi.org/10.1016/j.bbmt.2009.08.015 PMID: 20053331

[166] Kontoyiannis, D.P. Invasive mycoses: strategies for effective management. Am. J. Med., 2012, 125(1)(Suppl.), S25S38.

http://dx.doi.org/10.1016/j.amjmed.2011.10.009 PMID: 22196206

[167] Wang, J.L.; Chang, C.H.; Young-Xu, Y.; Chan, K.A. Systematic review and meta-analysis of the tolerability and hepatotoxicity of antifungals in empirical and definitive therapy for invasive fungal infection. Antimicrob. Agents Chemother., 2010, 54(6), 2409-2419.

http://dx.doi.org/10.1128/AAC.01657-09 PMID: 20308378

[168] Vermes, A.; Guchelaar, H.J.; Dankert, J. Flucytosine: a review of its pharmacology, clinical indications, pharmacokinetics, toxicity and drug interactions. J. Antimicrob. Chemother., 2000, 46(2), 171-179.

http://dx.doi.org/10.1093/jac/46.2.171 PMID: 10933638

[169] Yokoo, H.; Craig, R.M.; Harwood, T.R.; Cochrane, C. Griseofulvin-induced cholestasis in Swiss albino mice. Gastroenterology, 1979, 77(5), 1082-1087.

http://dx.doi.org/10.1016/S0016-5085(79)80081-5 PMID: 488635

[170] Wessely, Z.; Shapiro, S.H.; Klavins, J.V. Light and electron microscopy of hepatocellular changes in griseofulvin fed mice. Particular reference to Mallory bodies. Ann. Clin. Lab. Sci., 1979, 9(1), 24-36.

PMID: 420510

[171] Matilla, A.; Molland, E.A. A light and electron microscopic study of the liver in case of erythrohepatic protoporphyria and in griseofulvin-induced porphyria in mice. J. Clin. Pathol., 1974, 27(9), 698-709.

http://dx.doi.org/10.1136/jcp.27.9.698 PMID: 4372253

[172] Jadeja, D.; Jaiswal, C.S.; Panchasra, A.; Tripathi, C.B. Griseofulvin and/or terbinafine induced toxic epidermal necrolysis in an adult female patient-A case report. Curr. Drug Saf., 2016, 11(2), 192-194.

http://dx.doi.org/10.2174/1574886311666151223112645 PMID: 26695069

[173] Xing, Y.; Chen, L.; Feng, Y.; Zhou, Y.; Zhai, Y.; Lu, J. Meta-analysis of the safety of voriconazole in definitive, empirical, and prophylactic therapies for invasive fungal infections. BMC Infect. Dis., 2017, 17(1), 798. http://dx.doi.org/10.1186/s12879-017-2913-8 PMID: 29281997

[174] Greer, N.D. Posaconazole (Noxafil): a new triazole antifungal agent. Proc. Bayl. Univ. Med. Cent., 2007, 20(2), 188196.

http://dx.doi.org/10.1080/08998280.2007.11928283 PMID: 17431456

[175] Wingard, J.R.; White, M.H.; Anaissie, E.; Raffalli, J.; Goodman, J.; Arrieta, A. A randomized, double-blind comparative trial evaluating the safety of liposomal amphotericin B versus amphotericin B lipid complex in the empirical treatment of febrile neutropenia. L Amph/ABLC Collaborative Study Group. Clin. Infect. Dis., 2000, 31(5), 1155-1163.

http://dx.doi.org/10.1086/317451 PMID: 11073745

[176] Laniado-Laborín, R.; Cabrales-Vargas, M.N. Amphotericin B: side effects and toxicity. Rev. Iberoam. Micol., 2009, 26(4), 223-227.

http://dx.doi.org/10.1016/j.riam.2009.06.003 PMID: 19836985

[177] Maximova.; Schillani, G.; Simeone, R. Comparison of efficacy and safety of caspofungin versus micafungin in pedriatric allogeneic stem cell. Adv. Ther., 2017, 34, 1184-1199. http://dx.doi.org/10.1007/s12325-017-0534-7

[178] Roden, M.M.; Nelson, L.D.; Knudsen, T.A.; Jarosinski, P.F.; Starling, J.M.; Shiflett, S.E.; Calis, K.; DeChristoforo, R.; Donowitz, G.R.; Buell, D.; Walsh, T.J. Triad of acute infusion-related reactions associated with liposomal amphotericin B: analysis of clinical and epidemiological characteristics. Clin. Infect. Dis., 2003, 36(10), 1213-1220. http://dx.doi.org/10.1086/374553 PMID: 12746764

[179] Hamill, R.J. Amphotericin B formulations: a comparative review of efficacy and toxicity. Drugs, 2013, 73(9), 919934.

http://dx.doi.org/10.1007/s40265-013-0069-4 PMID: 23729001

[180] Lyu, X.; Zhao, C.; Yan, Z.M.; Hua, H. Efficacy of nystatin for the treatment of oral candidiasis: a systematic review and meta-analysis. Drug Des. Devel. Ther., 2016, 10, 11611171 .

http://dx.doi.org/10.2147/DDDT.S100795 PMID: 27042008

[181] França, F.D.; Tagliati, C.A.; Ferreira, A.; Chaves, M.M. Amphotericin B nephrotoxicity in vitro: Differential profile of PKC signaling in VERO and MDCK cell lines. Drugs, 2013, 9, 15-19.

[182] Kagan, S.; Ickowicz, D.; Shmuel, M.; Altschuler, Y.; Sionov, E.; Pitusi, M.; Weiss, A.; Farber, S.; Domb, A.J.; Polacheck, I. Toxicity mechanisms of amphotericin B and its neutralization by conjugation with arabinogalactan. Antimicrob. Agents Chemother., 2012, 56(11), 5603-5611. http://dx.doi.org/10.1128/AAC.00612-12 PMID: 22908154 
[183] Szoka, F.C.; Tang, M. Amphotericin B formulated in liposomes and lipid based systems: a review. J. Liposome Res., 1993, 3, 363-375.

http://dx.doi.org/10.3109/08982109309150726

[184] Espuelas, M.S.; Legrand, P.; Campanero, M.A.; Appel, M.; Chéron, M.; Gamazo, C.; Barratt, G.; Irache, J.M. Polymeric carriers for amphotericin B: in vitro activity, toxicity and therapeutic efficacy against systemic candidiasis in neutropenic mice. J. Antimicrob. Chemother., 2003, 52(3), 419-427.

http://dx.doi.org/10.1093/jac/dkg351 PMID: 12888593

[185] Temboot, P.; Usman, F.; Ul-Hag, Z.; Khalil, R.; Srichana, T. Biomolecular interactions of amphotericin B nanomicells with serum albumins: a combined biophysical and molecular dacking approah. Spectrochim. Acta. Mol. Biomol. Spectroc, 2018, 205, 442-456.

http://dx.doi.org/10.1016/j.saa.2018.07.057 PMID: 30055454

[186] Zia, Q.; Khan, A.A.; Swaleha, Z.; Owais, M. Selfassembled amphotericin B-loaded polyglutamic acid nanoparticles: preparation, characterization and in vitro potential against Candida albicans. Int. J. Nanomedicine, 2015, 10, 1769-1790.

PMID: 25784804

[187] Gharib, A.; Faezizadeh, Z.; Mohammad Asghari, H. Preparation and antifungal activity of spray-dried amphotericin B-loaded nanospheres. Daru, 2011, 19(5), 351-355. PMID: 22615681

[188] Randhawa, M.A.; Gondal, M.A.; Al-Zahrani, A.H.; Rashid, S.G.; Ali, A. Synthesis, morphology and antifungal activity of nanoparticulated amphotericin B, ketoconazole and thymoquinone against Candida albicans yeasts and Candida biofilm. J. Environ. Sci. Health. A. Tox. Hazar. Subst. Environ. Eng., 2015, 50, 119-124.

http://dx.doi.org/10.1080/10934529.2015.975042 PMID: 25560257

[189] Jain, S.; Valvi, P.U.; Swarnakar, N.K.; Thanki, K. Gelatin coated hybrid lipid nanoparticles for oral delivery of amphotericin B. Mol. Pharm., 2012, 9(9), 2542-2553. http://dx.doi.org/10.1021/mp300320d PMID: 22845020

[190] Jain, S.; Reddy, C.S.K.; Swami, R.; Kushwah, V. Amphotericin B loaded chitosan nanoparticles implication of bile salt stabilization on gastrointestinal stability, permeability and oral bioavailability. AAPS PharmSciTech, 2018, 19(7), 3152-3164.

http://dx.doi.org/10.1208/s12249-018-1153-6 PMID: 30136175

[191] Jabri, T.; Imran, M. Shafiullah.; Rao, K.; Ali, I.; Arfan, M.; Shah, M. R. Fabrication of lecithin-gum tragacanth mucoadesive hybrid nano-carrier system for in-vivo performance of amphotericin B. Carbohydr. Polym., 2018, 194, 89-96. http://dx.doi.org/10.1016/j.carbpol.2018.04.013 PMID: 29801862

[192] Ludwig, D.B.; de Camargo, L.E.A.; Khalil, N.M.; Auler, M.E.; Mainardes, R.M. Antifungal activity of chitosancoated Poly (lactic-co-glycolic) acid nanoparticles containing amphotericin B. Mycopathologia, 2018, 183(4), 659668.

http://dx.doi.org/10.1007/s11046-018-0253-x PMID: 29497926

[193] Ci, T.; Yuan, L.; Bao, X.; Hou, Y.; Wu, H.; Sun, H.; Cao, D.; Ke, X. Development and anti-Candida evaluation of the vaginal delivery system of amphotericin B nanosuspensionloaded thermogel. J. Drug Target., 2018, 26(9), 829-839. http://dx.doi.org/10.1080/1061186X.2018.1434660 PMID: 29378463
[194] Usman, F.; Khalil, R.; U1-Haq, Z.; Nakpheng, T.; Srichana, T. Bioactivity, safety, and efficacy of amphotericin B nanomicellar aerossol using sodium deoxycholate sulfate as the lipid carrier. AAPS PharmSciTech, 2018, 19(5), 20772086. http://dx.doi.org/10.1208/s12249-018-1013-4 PMID: 29691753

[195] Butani, D.; Yewale, C.; Misra, A. Topical Amphotericin B solid lipid nanoparticles: Design and development. Colloids Surf. B Biointerfaces, 2016, 139(139), 17-24. http://dx.doi.org/10.1016/j.colsurfb.2015.07.032 PMID: 26700229

[196] Fu, T.; Yi, J.; Lv, S.; Zhang, B. Ocular amphotericin B delivery by chitosan-modified nanostructured lipid carriers for fungal keratitis-targeted therapy. J. Liposome Res., 2017, 27(3), 228-233.

http://dx.doi.org/10.1080/08982104.2016.1224899 PMID: 27601177

[197] Grisin, T.; Bories, C.; Bombardi, M.; Loiseau, P.M.; Rouffiac, V.; Solgadi, A.; Mallet, J.M.; Ponchel, G.; Bouchemal, K. Supramolecular chitosan micro-platelets synergistically enhance anti-Candida albicans activity of amphotericin B using an immunocompetent murine model. Pharm. Res., 2017, 34(5), 1067-1082.

http://dx.doi.org/10.1007/s11095-017-2117-3 PMID: 28168390

[198] Serrano, D.R.; Lalatsa, A.; Dea-Ayuela, M.A.; BilbaoRamos, P.E.; Garrett, N.L.; Moger, J.; Guarro, J.; Capilla, J.; Ballesteros, M.P.; Schätzlein, A.G.; Bolás, F.; Torrado, J.J.; Uchegbu, I.F. Oral particle uptake and organ targeting drives the activity of amphotericin B nanoparticles. Mol. Pharm., 2015, 12(2), 420-431. http://dx.doi.org/10.1021/mp500527x PMID: 25558881

[199] Xu, N.; Gu, J.; Zhu, Y.; Wen, H.; Ren, Q.; Chen, J. Efficacy of intravenous amphotericin B-polybutylcyanoacrylate nanoparticles against cryptococcal meningitis in mice. Int. J. Nanomedicine, 2011, 6, 905-913. http://dx.doi.org/10.2147/IJN.S17503 PMID: 21720503

[200] Tang, X.; Jiao, R.; Xie, C.; Xu, L.; Huo, Z.; Dai, J.; Qian, Y.; Xu, W.; Hou, W.; Wang, J.; Liang, Y. Improved antifungal activity of amphotericin B-loaded TPGS-b-(PCLran-PGA) nanoparticles. Int. J. Clin. Exp. Med., 2015, 8(4), 5150-5162. PMID: 26131089

[201] Ahmad, A.; Wei, Y.; Syed, F.; Tahir, K.; Taj, R.; Khan, A.U.; Hameed, M.U.; Yuan, Q. Amphotericin B-conjugated biogenic silver nanoparticles as an innovative strategy for fungal infections. Microb. Pathog., 2016, 99, 271-281. http://dx.doi.org/10.1016/j.micpath.2016.08.031 PMID: 27591110

[202] Z.K.; Ma, Q.H.; Li, S.Y.; Zhang, D.Q.; Cong, L.; Tian, Y. L.; Yang, R.Y. The antifungal effect of silver nanoparticles on Trichosporon asahii. J. Microbiol. Immunol. Infect., 2016, 49(2), 1-7.

[203] Tutaj, K.; Szlazak, R.; Szalapata, K.; Starzyk, J.; Luchowski, R.; Grudzinski, W.; Osinska-Jaroszuk, M.; JaroszWilkolazka, A.; Szuster-Ciesielska, A.; Gruszecki, W.I. Amphotericin B-silver hybrid nanoparticles: synthesis, properties and antifungal activity. Nanomedicine (Lond.), 2016, 12(4), 1095-1103. http://dx.doi.org/10.1016/j.nano.2015.12.378 PMID: 26772425

[204] Saldanha, C.A.; Garcia, M.P.; Iocca, D.C.; Rebelo, L.G.; Souza, A.C.O.; Bocca, A.L.; Almeida Santos, Mde.F.; Morais, P.C.; Azevedo, R.B. Antifungal activity of amphotericin $\mathrm{B}$ conjugated to nanosized magnetite in the treatment 
of Paracoccidioidomycosis. PLoS Negl. Trop. Dis., 2016, 10(6)e 0004754

http://dx.doi.org/10.1371/journal.pntd.0004754 PMID: 27303789

[205] Diaz, I.L.; Parra, C.; Linarez, M.; Perez, L.D. Design of micelle nanocontainers based on PDMAEMA-b-PCL-bPDMAEMA triblock copolymers for the encapsulation of amphotericin B. AAPS PharmSciTech, 2015, 16(5), 10691078.

http://dx.doi.org/10.1208/s12249-015-0298-9 PMID: 25669917

[206] Chaudhari, M.B.; Desai, P.P.; Patel, P.A.; Patravale, V.B. Solid lipid nanoparticles of amphotericin B (AmbiOnp): in vitro and in vivo assessment towards safe and effective oral treatment module. Drug Deliv. Transl. Res., 2016, 6(4), 354-364.

PMID: 26712123

[207] Moraes Moreira Carraro, T.C.; Altmeyer, C.; Maissar Khalil, N.; Mara Mainardes, R. Assessment of in vitro antifungal efficacy and in vivo toxicity of Amphotericin Bloaded PLGA and PLGA-PEG blend nanoparticles. $J$. Mycol. Med., 2017, 27(4), 519-529.

http://dx.doi.org/10.1016/j.mycmed.2017.07.004 PMID: 28797532

[208] Rodrigues, C.D.; Khalil, N.M.; Mainardes, R.M. Determination of amphotericin B in PLA-PEG blend nanoparticles by HPLC-PDA. Braz. J. Pharm. Sci., 2014, 50(4), 2014. http://dx.doi.org/10.1590/S1984-82502014000400021

[209] Shim, Y.H.; Kim, Y.C.; Lee, H.J.; Bougard, F.; Dubois, P.; Choi, K.C.; Chung, C.W.; Kang, D.H.; Jeong, Y.I. Amphotericin $\mathrm{B}$ aggregation inhibition with novel nanoparticles prepared with poly(epsilon-caprolactone)/poly(n,ndimethylamino-2-ethyl methacrylate) diblock copolymer. $J$. Microbiol. Biotechnol., 2011, 21(1), 28-36. http://dx.doi.org/10.4014/jmb.1007.07041 PMID: 21301189

[210] Italia, J.L.; Sharp, A.; Carter, K.C.; Warn, P.; Kumar, M.N.V.R. Peroral amphotericin B polymer nanoparticles lead to comparable or superior in vivo antifungal activity to that of intravenous Ambisome ${ }^{\circledR}$ or Fungizone ${ }^{\mathrm{TM}}$. PLoS One, 2011, 6(10)e 25744

http://dx.doi.org/10.1371/journal.pone.0025744 PMID: 21998690

[211] Vroman, I.; Tighzert, L. Biodegradable polymers. Materials (Basel), 2009, 2(2), 307-344.

http://dx.doi.org/10.3390/ma2020307

[212] Song, S.H.; Lee, K.M.; Kang, J.B.; Lee, S.G.; Kang, M.J.; Choi, Y.W. Improved skin delivery of voriconazole with a nanostructured lipid carrier-based hydrogel formulation. Chem. Pharm. Bull. (Tokyo), 2014, 62(8), 793-798. http://dx.doi.org/10.1248/cpb.c14-00202 PMID: 25087631

[213] El-Hadidy, G.N.; Ibrahim, H.K.; Mohamed, M.I.; ElMilligi, M.F. Microemulsions as vehicles for topical administration of voriconazole: formulation and in vitro evaluation. Drug Dev. Ind. Pharm., 2012, 38(1), 64-72. http://dx.doi.org/10.3109/03639045.2011.590731 PMID: 21696340

[214] Khare, A.; Singh, I.; Pawar, P.; Grover, K. Design and evaluation of voriconazol loaded solid lipid nanoparticles for ophtalmic application. J. Drug Deliv., 2016, 20166590361

http://dx.doi.org/10.1155/2016/6590361 PMID: 27293896

[215] Cuming, R.S.; Abarca, E.M.; Duran, S.; Wooldridge, A.A.; Stewart, A.J.; Ravis, W.; Babu, R.J.; Lin, Y.J.; Hathcock, T. Development of a sustained-release voriconazol-containing thermogel for subconjunctival injection in horses. Invest. Ophthalmol. Vis. Sci., 2017, 58(5), 2746-2754. http://dx.doi.org/10.1167/iovs.16-20899 PMID: 28549089

[216] Füredi, P.; Pápay, Z.E.; Kovács, K.; Kiss, B.D.; Ludányi, K.; Antal, I.; Klebovich, I. Development and characterization of the voriconazole loaded lipid-based nanoparticles. $J$. Pharm. Biomed. Anal., 2017, 132, 184-189. http://dx.doi.org/10.1016/j.jpba.2016.09.047 PMID: 27750101

[217] Salem, H.F.; Kharshoum, R.M.; Abdel Hakim, L.F.; Abdelrahim, M.E. Edge activators and a polycationic polymer enhance the formulation of porous voriconazole nanoagglomerate for the use as a dry powder inhaler. J. Liposome Res., 2016, 26(4), 324-335.

http://dx.doi.org/10.3109/08982104.2016.1140182 PMID: 26872552

[218] Das, P.J.; Paul, P.; Mukherjee, B.; Mazumder, B.; Mondal, L.; Baishya, R.; Debnath, M.C.; Dey, K.S. Pulmonary delivery of voriconazol loaded nanoparticles providing a prolonged drug level in lungs- A promise for treating fungal infection. Mol. Pharm., 2015, 12(8), 2651-2664.

http://dx.doi.org/10.1021/acs.molpharmaceut.5b00064 PMID: 25941882

[219] Paul, P.; Sengupta, S.; Mukherjee, B.; Shaw, T.K.; Gaonkar, R.H.; Debnath, M.C. Chitosan-coated nanoparticles enhanced lung pharmacokinetic profile of voriconazole upon pulmonary delivery in mice. Nanomedicine (Lond.), 2018, 13(5), 501-520.

http://dx.doi.org/10.2217/nnm-2017-0291 PMID: 29383985

[220] Gratieri, T.; Krawczyk-Santos, A.P.; Rocha, P.B.R.; CunhaFilho, M.; Gelfuso, G.M.; Marreto, R.N.; Taveira, S.F. SLN-and NLC-encapsulating antifungal agentes: skin drug delivery and their unexplored potential for treating onychomycosis. Curr. Pharm. Dis., 2017, 23(43), 6684-6695.

[221] Huang, J.F.; Zhong, J.; Chen, G.P.; Lin, Z.T.; Deng, Y.; Liu, Y.L.; Cao, P.Y.; Wang, B.; Wei, Y.; Wu, T.; Yuan, J.; Jiang, G.B. A hydrogel-based hybrid theranostic contact lens for fungal keratitis. ACS Nano, 2016, 10(7), 64646473. http://dx.doi.org/10.1021/acsnano.6b00601 PMID: 27244244

[222] Pawar, P.; Kashyap, H.; Malhotra, S.; Sindhu, R. Hp- $\beta-C D-$ voriconazole in situ gelling system for ocular drug delivery: in vitro, stability, and antifungal activities assessment. BioMed Res. Int., 2013, 2013341218 http://dx.doi.org/10.1155/2013/341218 PMID: 23762839

[223] Gupta, M.; Vyas, S.P. Development, characterization and in vivo assessment of effective lipidic nanoparticles for dermal delivery of fluconazole against cutaneous candidiasis. Chem. Phys. Lipids, 2012, 165(4), 454-461.

http://dx.doi.org/10.1016/j.chemphyslip.2012.01.006 PMID: 22309657

[224] Longhi, C.; Santos, J.P.; Morey, A.T.; Marcato, P.D.; Durán, N.; Pinge-Filho, P.; Nakazato, G.; Yamada-Ogatta, S.F.; Yamauchi, L.M. Combination of fluconazole with silver nanoparticles produced by Fusarium oxysporum improves antifungal effect against planktonic cells and biofilm of drug-resistant Candida albicans. Med. Mycol., 2016, 54(4), 428-432.

http://dx.doi.org/10.1093/mmy/myv036 PMID: 26092103

[225] Moazeni, M.; Kelidari, H.R.; Saeedi, M.; Morteza-Semnani, K.; Nabili, M.; Gohar, A.A.; Akbari, J.; Lotfali, E.; Nokhodchi, A. Time to overcome fluconazole resistant Candida isolates: Solid lipid nanoparticles as a novel antifungal drug delivery system. Colloids Surf. B Biointerfaces, 2016, 142, 400-407.

http://dx.doi.org/10.1016/j.colsurfb.2016.03.013 PMID: 26974361 
[226] Mohammed, N.; Rejinold, N.S.; Mangalathillam, S.; Biswas, R.; Nair, S.V.; Jayakumar, R. Fluconazole loaded chitin nanogels as a topical ocular drug delivery agent for corneal fungal infections. J. Biomed. Nanotechnol., 2013, 9(9), 1521-1531.

http://dx.doi.org/10.1166/jbn.2013.1647 PMID: 23980500

[227] Zakir, F.; Vaidya, B.; Goyal, A.K.; Malik, B.; Vyas, S.P. Development and characterization of oleic acid vesicles for the topical delivery of fluconazole. Drug Deliv., 2010, 17(4), 238-248.

http://dx.doi.org/10.3109/10717541003680981 PMID: 20235758

[228] Moustafa, M.A.; Elnaggar, Y.S.R.; El-Refaie, W.M.; Abdallah, O.Y. Hyalugel-integrated liposomes as a novel ocular nanosized delivery system of fluconazole with promising prolonged effect. Int. J. Pharm., 2017, 534(1-2), 14-24. http://dx.doi.org/10.1016/j.ijpharm.2017.10.007 PMID: 28987453

[229] Kelidari, H.R.; Moazeni, M.; Babaei, R.; Saeedi, M.; Akbari, J.; Parkoohi, P.I.; Nabili, M.; Gohar, A.A.; MortezaSemnani, K.; Nokhodchi, A. Improved yeast delivery of fluconazole with a nanostructured lipid carrier system. Biomed. Pharmacother., 2017, 89, 83-88.

http://dx.doi.org/10.1016/j.biopha.2017.02.008 PMID: 28222399

[230] Modi, J.; Joshi, G.; Sawant, K. Chitosan based mucoadhesive nanoparticles of ketoconazole for bioavailability enhancement: formulation, optimization, in vitro and ex vivo evaluation. Drug Dev. Ind. Pharm., 2013, 39(4), 540-547. http://dx.doi.org/10.3109/03639045.2012.666978 PMID: 22436084

[231] Winnicka, K.; Wroblewska, M.; Wieczorek, P.; Sacha, P.T.; Tryniszewska, E. Hydrogel of ketoconazole and PAMAM dendrimers: formulation and antifungal activity. Molecules, 2012, 17(4), 4612-4624.

http://dx.doi.org/10.3390/molecules17044612 PMID: 22513487

[232] Martin, B.; Brouillet, F.; Franceschi, S.; Perez, E. Evaluation of organogel nanoparticles as drug delivery system for lipophilic compounds. AAPS PharmSciTech, 2017, 18(4), 1261-1269.

http://dx.doi.org/10.1208/s12249-016-0587-y PMID: 27480442

[233] Kumar, S.; Kaur, P.; Bernela, M.; Rani, R.; Thakur, R. Ketoconazole encapsulated in chitosan-gellan gum nanocomplexes exhibits prolonged antifungal activity. Int. J. Biol. Macromol., 2016, 93(Pt A), 988-994.

http://dx.doi.org/10.1016/j.ijbiomac.2016.09.042 PMID: 27659003

[234] Mahtab, A.; Anwar, M.; Mallick, N.; Naz, Z.; Jain, G.K.; Ahmad, F.J. Transungual delivery of ketoconazole nanoemulgel for the effective management of onychomycosis. AAPS PharmSciTech, 2016, 17(6), 1477-1490.

http://dx.doi.org/10.1208/s12249-016-0488-0 PMID: 26857516

[235] Ahmed, T.A.; Aljaeid, B.M. A potential in situ gel formulation loaded with novel fabricated poly(lactide-co-glycolide) nanoparticles for enhancing and sustaining the ophthalmic delivery of ketoconazole. Int. J. Nanomedicine, 2017, 12, 1863-1875.

http://dx.doi.org/10.2147/IJN.S131850 PMID: 28331311

[236] Jared, S.R.; Rao, J.P.; Subramani, S. Actions of antidiuretic hormone analogues on intact and nystatin-permeabilized frog skins. Exp. Physiol., 2009, 94(12), 1174-1184. http://dx.doi.org/10.1113/expphysiol.2009.048934 PMID: 19666695
[237] Mohammadi, G.; Shakeri, A.; Fattahi, A.; Mohammadi, P.; Mikaeili, A.; Aliabadi, A.; Adibkia, K. Preparation, physicochemical characterization and anti-fungal evaluation of nystatin-loaded PLGA-glucosamine nanoparticles. Pharm. Res., 2017, 34(2), 301-309. http://dx.doi.org/10.1007/s11095-016-2062-6 PMID: 27928646

[238] Fernández-Campos, F.; Clares Naveros, B.; López Serrano, O.; Alonso Merino, C.; Calpena Campmany, A.C. Evaluation of novel nystatin nanoemulsion for skin candidosis infections. Mycoses, 2013, 56(1), 70-81. http://dx.doi.org/10.1111/j.1439-0507.2012.02202.x PMID: 22574899

[239] Khalil, R.M.; El-Rahman, A.A.A.; Kassem, M.A.; El-Ridi, S.S.; Samra, M.M.A.; Awad, G.E.A.; Mansy, S.S. Preparation and in vivo assessment of nystatin-loaded solid lipid nanoparticles for topical delivery against cutaneous candidiasis. Int. Sch. Scien. Reser. Innov, 2014, 8(7), 1-9.

[240] Salem, H.F.; Ahmed, S.M.; Hassaballah, A.E.; Omar, M.M. Targeting brain cells with glutathione-modulated nanoliposomes: in vitro and in vivo study. Drug Des. Devel. Ther., 2015, 9, 3705-3727.

http://dx.doi.org/10.2147/DDDT.S85302 PMID: 26229435

[241] Tian, B.; Yan, Q.; Wang, J.; Ding, C.; Sai, S. Enhanced antifungal activity of voriconazole-loaded nanostructured lipid carriers against Candida albicans with a dimorphic switching model. Int. J. Nanomedicine, 2017, 12, 71317141.

http://dx.doi.org/10.2147/IJN.S145695 PMID: 29026306

[242] de Sá, F.A.; Taveira, S.F.; Gelfuso, G.M.; Lima, E.M.; Gratieri, T. Liposomal voriconazole (VOR) formulation for improved ocular delivery. Colloids Surf. B Biointerfaces, 2015, 133, 331-338.

http://dx.doi.org/10.1016/j.colsurfb.2015.06.036 PMID: 26123854

[243] Pandurangan, D.K.; Bodagala, P.; Palanirajan, V.K.; Govindaraj, S. Formulation and evaluation of voriconazole ophthalmic solid lipid nanoparticles in situ gel. Int. J. Pharm. Investig., 2016, 6(1), 56-62.

http://dx.doi.org/10.4103/2230-973X.176488 PMID: 27014620

[244] Kumar, R.; Sinha, V.R. Solid lipid nanoparticle: an efficient carrier for improved ocular permeation of voriconazole. Drug Dev. Ind. Pharm., 2016, 42(12), 1956-1967. http://dx.doi.org/10.1080/03639045.2016.1185437 PMID: 27143048

[245] Takalkar, D.; Desai, N. Nanolipid gel of an antimycotic drug for treating vulvovaginal candidiasis - development and evaluation. AAPS PharmSciTech, 2018, 19(3), 12971307.

http://dx.doi.org/10.1208/s12249-017-0918-7 PMID: 29340981

[246] Gómez-Sequeda, N.; Torres, R.; Ortiz, C. Synthesis, characterization, and in vitro activity against Candida spp. of fluconazole encapsulated on cationic and conventional nanoparticles of poly(lactic-co-glycolic acid). Nanotechnol. Sci. Appl., 2017, 10, 95-104.

http://dx.doi.org/10.2147/NSA.S96018 PMID: 28572725

[247] Gupta, M.; Vaidya, B.; Mishra, N.; Vyas, S.P. Effect of surfactants on the characteristics of fluconazole niosomes for enhanced cutaneous delivery. Artif. Cells Blood Substit. Immobil. Biotechnol., 2011, 39(6), 376-384. http://dx.doi.org/10.3109/10731199.2011.611476 PMID: 21951195

[248] Domingues Bianchin, M.; Borowicz, S.M.; da Rosa Monte Machado, G.; Pippi, B.; Stanisçuaski Guterres, S.; Raffin 
Pohlmann, A.; Meneghello Fuentefria, A.; Clemes Külkamp-Guerreiro, I. Lipid core nanoparticles as a broad strategy to reverse fluconazole resistance in multiple Candida species. Colloids Surf. B Biointerfaces, 2019, 175, 523-529.

http://dx.doi.org/10.1016/j.colsurfb.2018.12.011 PMID: 30579053

[249] Gupta, M.; Tiwari, S.; Vyas, S.P. Influence of various lipid core on characteristics of SLNs designed for topical delivery of fluconazole against cutaneous candidiasis. Pharm. Dev. Technol., 2013, 18(3), 550-559. http://dx.doi.org/10.3109/10837450.2011.598161 PMID: 21810069

[250] Sharma, R.; Garg, T.; Goyal, A.K.; Rath, G. Development, optimization and evaluation of polymeric electrospun nanofiber: A tool for local delivery of fluconazole for management of vaginal candidiasis. Artif. Cells Nanomed. Biotechnol., 2016, 44(2), 524-531.

http://dx.doi.org/10.3109/21691401.2014.966194 PMID: 25315503

[251] Bors, A.; Niculae, G.; Stan, R.; Meghea, A. Lipid nanocarriers with antifungal activity prepared by high pressure homogenization. Rev. Chim., 2014, 65, 671-675.

[252] Martín-Villena, M.J.; Fernández-Campos, F.; CalpenaCampmany, A.C.; Bozal-de Febrer, N.; Ruiz-Martínez, M.A.; Clares-Naveros, B. Novel microparticulate systems for the vaginal delivery of nystatin: development and characterization. Carbohydr. Polym., 2013, 94(1), 1-11. http://dx.doi.org/10.1016/j.carbpol.2013.01.005 PMID: 23544502

[253] Martín, M.J.; Calpena, A.C.; Fernández, F.; Mallandrich, M.; Gálvez, P.; Clares, B. Development of alginate microspheres as nystatin carriers for oral mucosa drug delivery. Carbohydr. Polym., 2015, 117, 140-149. http://dx.doi.org/10.1016/j.carbpol.2014.09.032 PMID: 25498619

[254] Gupta, P.K.; Jaiswal, A.K.; Asthana, S.; Verma, A.; Kumar, V.; Shukla, P.; Dwivedi, P.; Dube, A.; Mishra, P.R. Self assembled ionically sodium alginate cross-linked amphotericin B encapsulated glycol chitosan stearate nanoparticles: applicability in better chemotherapy and non-toxic delivery in visceral leishmaniasis. Pharm. Res., 2015, 32(5), 1727-1740.

http://dx.doi.org/10.1007/s11095-014-1571-4 PMID: 25425053

[255] Yang, C.; Xue, B.; Song, W.; Kan, B.; Zhang, D.; Yu, H.; Shen, N.; Li, X.; Tang, Z.; Chen, X. Reducing the toxicity of amphotericin B by encapsulation using methoxy poly(ethylene glycol)-b-poly(l-glutamic acid-co-lphenylalanine). Biomater. Sci., 2018, 6(8), 2189-2196. http://dx.doi.org/10.1039/C8BM00506K PMID: 29947373

[256] Chhonker, Y.S.; Prasad, Y.D.; Chandasana, H.; Vishvkarma, A.; Mitra, K.; Shukla, P.K.; Bhatta, R.S. Amphotericin-B entrapped lecithin/chitosan nanoparticles for prolonged ocular application. Int. J. Biol. Macromol., 2015, 72, 1451-1458.

http://dx.doi.org/10.1016/j.ijbiomac.2014.10.014 PMID: 25453292

[257] Tang, X.; Zhu, H.; Sun, L.; Hou, W.; Cai, S.; Zhang, R.; Liu, F. Enhanced antifungal effects of amphotericin BTPGS-b-(PCL-ran-PGA) nanoparticles in vitro and in vivo. Int. J. Nanomedicine, 2014, 9, 5403-5413. PMID: 25473279

[258] Zhang, P.; Yang, X.; He, Y.; Chen, Z.; Liu, B.; Emesto, C.S.; Yang, G.; Wang, W.; Zhang, J.; Lin, R. Preparation, characterization and toxicity evaluation of amphotericin $\mathrm{B}$ loaded MPEG-PCL micelles and its application for buccal tablets. Appl. Microbiol. Biotechnol., 2017, 101(19), 73577370 .

http://dx.doi.org/10.1007/s00253-017-8463-6 PMID: 28868587

[259] Hussain, A.; Singh, V.K.; Singh, O.P.; Shafaat, K.; Kumar, S.; Ahmad, F.J. Formulation and optimization of nanoemulsion using antifungal lipid and surfactant for accentuated topical delivery of Amphotericin B. Drug Deliv., 2016, 23(8), 3101-3110.

http://dx.doi.org/10.3109/10717544.2016.1153747 PMID: 27854145

[260] Sandhya, M.; v, A.; Maneesha K, S.; Raja, B.; R, J.; S, S. Amphotericin B loaded sulfonated chitosan nanoparticles for targeting macrophages to treat intracellular Candida glabrata infections. Int. J. Biol. Macromol., 2018, 110, 133139.

http://dx.doi.org/10.1016/j.ijbiomac.2018.01.028 PMID: 29339278

[261] Zhou, W.; Wang, Y.; Jian, J.; Song, S. Self-aggregated nanoparticles based on amphiphilic poly(lactic acid)grafted-chitosan copolymer for ocular delivery of amphotericin B. Int. J. Nanomedicine, 2013, 8, 3715-3728. PMID: 24106427

[262] Zu, Y.; Sun, W.; Zhao, X.; Wang, W.; Li, Y.; Ge, Y.; Liu, Y.; Wang, K. Preparation and characterization of amorphous amphotericin B nanoparticles for oral administration through liquid antisolvent precipitation. Eur. J. Pharm. Sci., 2014, 53, 109-117.

http://dx.doi.org/10.1016/j.ejps.2013.12.005 PMID: 24345795

[263] Zhao, M.; Hu, J.; Zhang, L.; Zhang, L.; Sun, Y.; Ma, N.; Chen, X.; Gao, Z. Study of amphotericin B magnetic liposomes for brain targeting. Int. J. Pharm., 2014, 475(12), 9-16.

http://dx.doi.org/10.1016/j.ijpharm.2014.08.035 PMID: 25151436

[264] Bhatia, S.; Kumar, V.; Sharma, K.; Nagpal, K.; Bera, T. Significance of algal polymer in designing amphotericin $B$ nanoparticles; Scientific W. J., 2014, pp. 1-21.

[265] Pippa, N.; Mariaki, M.; Pispas, S.; Demetzos, C. Preparation, development and in vitro release evaluation of amphotericin B-loaded amphiphilic block copolymer vectors. Int. J. Pharm., 2014, 473(1-2), 80-86.

http://dx.doi.org/10.1016/j.ijpharm.2014.07.001 PMID: 24998505

[266] Richter, A.R.; Feitosa, J.P.A.; Paula, H.C.B.; Goycoolea, F.M.; de Paula, R.C.M. Pickering emulsion stabilized by cashew gum- poly-1-lactide copolymer nanoparticles: Synthesis, characterization and amphotericin B encapsulation. Colloids Surf. B Biointerfaces, 2018, 164, 201-209. http://dx.doi.org/10.1016/j.colsurfb.2018.01.023 PMID: 29413597

[267] Yang, M.; Du, K.; Hou, Y.; Xie, S.; Dong, Y.; Li, D.; Du, Y. Synergistic antifungal effect of amphotericin B-loaded PLGA nanoparticle with ultrasound against $C$. albicans biofilms. Antimicrob. Agents Chemother., 2019, 63(4), 2022-18. http://dx.doi.org/10.1128/AAC.02022-18

[268] Aparna, V.; Melge, A.R.; Rajan, V.K.; Biswas, R.; Jayakumar, R.; Gopi Mohan, C. Carboxymethylated carrageenan conjugated amphotericin B loaded gelatin nanoparticles for treating intracellular Candida glabrata infections. Int. J. Biol. Macromol., 2018, 110, 140-149. http://dx.doi.org/10.1016/j.ijbiomac.2017.11.126 PMID: 29169943 
[269] Tan, S.W.; Billa, N. Lipid effects on expulsion rate of amphotericin B from solid lipid nanoparticles. AAPS PharmSciTech, 2014, 15(2), 287-295.

http://dx.doi.org/10.1208/s12249-013-0056-9 PMID: 24318197

[270] Nahar, M.; Mishra, D.; Dubey, V.; Jain, N.K. Development, characterization, and toxicity evaluation of amphotericin Bloaded gelatin nanoparticles. Nanomedicine (Lond.), 2008, 4(3), 252-261

http://dx.doi.org/10.1016/j.nano.2008.03.007 PMID: 18502187

[271] Van den Bossche, H.; Willemsens, G.; Cools, W.; Marichal, P.; Lauwers, W. Hypothesis on the molecular basis of the antifungal activity of N-substituted imidazoles and triazoles. Biochem. Soc. Trans., 1983, 11(6), 665-667. http://dx.doi.org/10.1042/bst0110665 PMID: 6667774

[272] Bianco, M.A.; Gallarate, M.; Trotta, M.; Battaglia, L. Amphotericin B loaded SLN prepared with the coacervation technicque. J. Drug Deliv. Sci. Technol., 2010, 20(3), 187191. http://dx.doi.org/10.1016/S1773-2247(10)50028-5

[273] Vakil, R.; Knilans, K.; Andes, D.; Kwon, G.S. Combination antifungal therapy involving amphotericin $\mathrm{B}$, rapamycin and 5-fluorocytosine using PEG-phospholipid micelles. Pharm. Res., 2008, 25(9), 2056-2064.

http://dx.doi.org/10.1007/s11095-008-9588-1 PMID: 18415047

[274] Baumgartner, J.; Bertinetti, L.; Widdrat, M.; Hirt, A.M.; Faivre, D. Formation of magnetite nanoparticles at low temperature: from superparamagnetic to stable single domain particles. PLoS One, 2013, 8(3)e57070 http://dx.doi.org/10.1371/journal.pone.0057070 PMID: 23520462

[275] Goy, R.C.; De Brito, D.; Assis, O.B.G. A Review of the antimicrobial activity of chitosan. Pol: Ciên. Tecnol, 2009, 19(3), 241-247.

[276] Sun, L.; Liao, K.; Li, Y.; Zhao, L.; Liang, S.; Guo, D.; Hu, J.; Wang, D. Synergy between polyvinylpyrrolidone-coated silver nanoparticles and azole antifungal against drugresistant Candida albicans. J. Nanosci. Nanotechnol., 2016, 16(3), 2325-2335. http://dx.doi.org/10.1166/jnn.2016.10934 PMID: 27455637

[277] Costa, A.F.; Araujo, D.E.; Cabral, M.S.; Brito, I.T.; Leite, L.B.M.; Pereira, M.; Amaral, A.C. Development, characterization, and in vitro-in vivo evaluation miconazole and farnesol for treatment of vulvovaginal candidiasis. Med. Mycol., 2018, 57(1), 52-62. http://dx.doi.org/10.1093/mmy/myx 155 PMID: 29361177

[278] Kalita, S.; Kandimalla, R.; Devi, B.; Kalita, B.; Kalita, K.; Deka, M.; Kataki, A.C.; Sharma, A.; Kotoky, J. Dual delivery of chloramphenicol and essential oil by poly-ecaprolactone-Pluronic nanocapsules to treat MRSACandida co-infected chronic burn wounds. RSC Advances, 2017, 7(3), 1749-1758.

http://dx.doi.org/10.1039/C6RA26561H

[279] Svetlichny, G.; Külkamp-Guerreiro, I.C.; Cunha, S.L.; Silva, F.E.; Bueno, K.; Pohlmann, A.R.; Fuentefria, A.M.; Guterres, S.S. Solid lipid nanoparticles containing copaiba oil and allantoin: development and role of nanoencapsulation on the antifungal activity. Pharmazie, 2015, 70(3), 155-164. PMID: 25980176

[280] Diezi, T.A.; Kwon, G. Amphotericin B/sterol co-loaded PEG-phospholipid micelles: effects of sterols on aggregation state and hemolytic activity of amphotericin B. Pharm. Res., 2012, 29(7), 1737-1744. http://dx.doi.org/10.1007/s1 1095-011-0626-z PMID: 22130733

[281] Vitonyte, J.; Manca, M.L.; Caddeo, C.; Valenti, D.; Peris, J.E.; Usach, I.; Nacher, A.; Matos, M.; Gutiérrez, G.; Orrù, G.; Fernàndez-Busquets, X.; Fadda, A.M.; Manconi, M. Bifunctional viscous nanovesicles co-loaded with resveratrol and gallic acid for skin protection against microbial and oxidative injuries. Eur. J. Pharm. Biopharm., 2017, 114, 278-287.

http://dx.doi.org/10.1016/j.ejpb.2017.02.004 PMID: 28192250

[282] Jogaiah, S.; Kurjogi, M.; Abdelrahman, M.; Hanumanthappa, N.; Tran, L-S.P. Ganoderma applanatum -mediated green synthesis of silver nanoparticles: Structural characterization, and in vitro and in vivo biomedical and agrochemical properties. Arab. J. Chem., 2019, 12, 1108-1120. http://dx.doi.org/10.1016/j.arabjc.2017.12.002

[283] Sarkar, J.; Chakraborty, N.; Chatterjee, A.; Bhattacharjee, A.; Dasgupta, D.; Acharya, K. Green synthesized copper oxide nanoparticles ameliorate defence and antioxidant enzymes in Lens culinaris. Nanomaterials (Basel), 2020, $10(2), 312$.

http://dx.doi.org/10.3390/nano10020312 PMID: 32059367

[284] Thakur, B.K.; Kumar, A.; Kumar, D. Green synthesis of titanium dioxide nanoparticles using Azadirachta indica leaf extract and evaluation of their antibacterial activity. $S$. Afr. J. Bot., 2019, 124, 223-227.

http://dx.doi.org/10.1016/j.sajb.2019.05.024

[285] Nandini, B.; Puttaswamy, H.; H S, P.; Adhikari, S.; Jogaiah, S.; Nagaraja, G. Elicitation of novel trichogenic-lipid nanoemulsion signaling resistance against pearl millet downy mildew disease. Biomolecules, 2019, 10(1)E25 http://dx.doi.org/10.3390/biom10010025 PMID: 31878099

[286] Nayak, S.; Bhat, M. P.; Udayashankar, A. C.; Lakshmeesha, T. R.; Geetha, N.; Jogaiah, S. Biosynthesis and characterization of Dillenia indica mediated silver nanoparticles and their biological activity. Appl. Organometal. Chem., 2020, e5567, 1-9.

[287] Bhatnagar, S.; Kobori, T.; Ganesh, D.; Ogawa, K.; Aoyagi, $\mathrm{H}$. Biosynthesis of silver nanoparticles mediated by extracellular pigment from Talaromyces purpurogenus and their biomedical applications. Nanomaterials (Basel), 2019, 9(7), 1042. http://dx.doi.org/10.3390/nano9071042 PMID: 31330905

[288] Riaz, M.; Altaf, M.; Khan, M.Q.; Manzoor, S.; Shekheli, M.A.; Shah, M.A.; Ilyas, S.Z.; Hussain, Z. Green synthesis of silver nanoparticles using Jurinea dolomiaea and biological activities. J. Nanosci. Nanotechnol., 2018, 18(12), 8386-8391. http://dx.doi.org/10.1166/jnn.2018.16401 PMID: 30189964

[289] Jaffri, S.B.; Ahmad, K.S. Biomimetic detoxifier Prunus cerasifera Ehrh. silver nanoparticles: innate green bullets for morbific pathogens and persistent pollutants. Environ. Sci. Pollut. Res. Int., 2020, 1-17. http://dx.doi.org/10.1007/s11356-020-07626-6 PMID: 31925686

[290] Fernández-Campos, F.; Calpena-Campmany, A.C.; Rodríguez-Delgado, G.; López-Serrano, O.; Claves-Naveros, B. Development and characterization of a treatment of candidosis: ultrastructural effects and release studies. J. Pharm. Sci., 2012, 101(10), 3739-3752. http://dx.doi.org/10.1002/jps.23249 PMID: 22777575

[291] Krpetić, Z.; Anguissola, S.; Garry, D.; Kelly, P.M.; Dawson, K.A. Nanomaterials: impact on cells and cell organelles. Adv. Exp. Med. Biol., 2014, 811, 135-156. 
http://dx.doi.org/10.1007/978-94-017-8739-0_8 PMID: 24683031

[292] Tosi, G.; Duskey, J.T.; Kreuter, J. Nanoparticles as carriers for drug delivery of macromolecules across the blood-brain barrier. Expert Opin. Drug Deliv., 2020, 17(1), 23-32. http://dx.doi.org/10.1080/17425247.2020.1698544 PMID: 31774000

[293] Patel, S.; Jana, S.; Chetty, R.; Thakore, S.; Singh, M.; Devkar, R. Toxicity evaluation of magnetic iron oxide nanoparticles reveals neuronal loss in chicken embryo. Drug Chem. Toxicol., 2019, 42(1), 1-8.

http://dx.doi.org/10.1080/01480545.2017.1413110 PMID: 29281933

[294] Sohaebuddin, S.K.; Thevenot, P.T.; Baker, D.; Eaton, J.W.; Tang, L. Nanomaterial cytotoxicity is composition, size, and cell type dependent. Part. Fibre Toxicol., 2010, 7(1), 22.

http://dx.doi.org/10.1186/1743-8977-7-22 PMID: 20727197

DISCLAIMER: The above article has been published in Epub (ahead of print) on the basis of the materials provided by the author. The Editorial Department reserves the right to make minor modifications for further improvement of the manuscript. 